\title{
The Role of Debt in Interactive Corporate Governance
}

\author{
George G. Triantis $\dagger$ \\ Ronald J. Danielst
}

Most of the corporate governance literature rests on a premise that the interests of various stakeholder groups conflict and that managerial loyalty is more likely to be captured by shareholders than any other constituency. Yet, stakeholder interests do converge in the objective of controlling managerial slack and nonequity constituents have substantial influence over firm decisions. Although the study of governance has taken early steps to abandon its preoccupation with equity-centered solutions and identify interdependencies existing among a broader range of stakeholders, governance scholars have missed an important element of interactivity. A stakeholder reacts to the actions of others and thereby contributes to the collective interest in controlling slack. Each stakeholder has a window on the firm through which it can acquire some type of information at lower cost than other stakeholders. When a stakeholder detects an unsatisfactory state of affairs, it reacts by choosing to exit or exercise voice. The exercise of either the voice or exit option may pressure management to correct the unsatisfactory state of slack. More to the point, however, a stakeholder's exit bears important information for other stakeholders, at least some of whom may be better placed to take action that corrects the slack.

This Article describes an interactive system of corporate governance and provides a stylized theory of the role of lenders within this system. The divergence in the interests of these lenders and other stakeholders does not preclude interactive governance, but it does threaten to reduce the net benefits from the process. Therefore, the authors identify a number of legal and institutional mechanisms that help to channel the efforts of the lender toward the common goal of containing and correcting managerial slack.

Copyright $\odot 1995$ California Law Review, Inc.

$\dagger$ Professor of Law, University of Virginia.

$\ddagger$ Associate Professor of Law and Dean, University of Toronto. We thank Barry Adler, Ian Ayres, Bruce Chapman, George Cohen, Michael Dooley, Clay Gillette, Ron Gilson, Marcel Kahan, Ed Kitch, Mike Klausner, Lynn LoPucki, Paul Mahoney, Bob Rasmussen, Roberta Romano, Joan Schmit, Robert Scott, David Skeel, Peter Swire, Michael Trebilcock, Larry Walker, and Steve Walt for helpful comments on an earlier draft of this paper. We also benefited from presentations of the earlier draft at George Mason, Georgetown, Virginia, and Wisconsin law schools, at Toronto faculty of management, and at the 1993 meetings of the American Law and Economics Association. We thank Jason Krikorian, David Steinberg, and Mark Wiseman for diligent research assistance. 
The interactive perspective thus permits new explanations for phenomena such as debt covenants, bankruptcy preference rules and lender liability laws. For example, the definition of debt covenants and events of default in lending agreements raise the likelihood that the lender exit is prompted by slack rather than lender opportunism and thereby enhances the informational value of the exit. Bankruptcy preference rules encourage early exit before the firm becomes insolvent, thereby enabling remaining stakeholders to take action before the firm's condition becomes irreparable. Thus, debt covenants and preference rules provide a window that increases the value of lender exit in prompting the correction of managerial slack.

\section{INTRODUCTION}

Berle and Means set the terms of the modern corporate governance debate by observing the separation of ownership and control in the modern American corporation. ${ }^{1}$ The divergence in interest between owners (the shareholders) and those who control the decisions of the firm (the managers) is now well understood through managerial agency theory. In this light, shareholders are justifiably concerned about managerial behavior that impedes the maximization of firm value: notably, lapses in inanagerial competence or effort, managerial entrenchment or empire building, and excessive managerial compensation or perquisite consumption. We refer to these problems collectively as managerial slack. "We use the term "slack" to indicate that these problems can be remedied, particularly if they are detected early. One example of managerial slack is the failure of management to react effectively to changes in a firm's environment. The demise of a corporation is often attributed to such exogenous changes as, for example, decreases im demand for the firm's products or mcreases in its costs. Yet, managerial slack in the form of failure to react effectively to the changes, and the corresponding delay in detecting and correcting such slack, are ultimately more interesting causes of business failure than the shocks themselves.

In his Presidential Address to the American Finance Association in 1993, Michael Jensen observed that a modern industrial revolution has taken place since the early 1970 s, in which technological advances, organizational innovation, deregulation, and the expansion of global trade have created excess capacity in many industries. ${ }^{3}$ Firms in those industries (particularly the relatively high-cost businesses) should respond by downsizing

1. Adolf A. Berle, Jr. \& Gardiner C. Means, The Modern Corporation and Private Property (1932).

2. The term "slack" comes from Albert O. Hirschman. Albert O. Hirschman, Exit, Voice, and Loyalty: Responses to Decline in Firms, Organizations, and States 10-15 (1970). Hirschman attributes the concept to Richard M. Cyert \& JAMES G. MarCH, A BeHAvioral ThEORY OF THE FIRM (1963). HIRSCHMAN, supra, at 11 n.7.

3. Michael C. Jensen, The Modern Industrial Revolution, Exit, and the Failure of Internal Control Systems, 48 J. Fin. 831, 835-47 (1993). 
or shutting down production. Ultimately, the unavoidable discipline of product markets forces such firms to reach this result. Yet, exit driven by product-market discipline comes later and at a significantly higher cost than if it were effected by a firm adjusting promptly and continuously to exogenous changes. Such timely action, however, is impeded by managerial slack and employee resistance.

The study of corporate governance is the exammation of mechanisms that deter and correct managerial slack. Scholars divide these mechanisms into internal and external disciplimary forces. A firm's internal control system includes its board of directors ${ }^{4}$ (particularly outside directors), ${ }^{5}$ the proxy voting process, ${ }^{6}$ shareholder proposals, ${ }^{7}$ and fiduciary duties owed by directors to the firm. ${ }^{8}$ The external discipline comes from the markets in which the managers and their firms compete: the managerial labor inar-

4. At one time, the board of directors was viewed as an institutional panacea for accountability problems. See, e.g., Victor Brudney, The Independent Director-Heavenly City or Potemkin Village?, 95 HaRv. L. REv. 597, 597-600 (1982) (discussing idea of independent director as "legitimator of corporate power"); see also Melvin A. Eisenberg, Legal Models of Management Structure in the Modern Corporation: Officers, Directors, and Accountants, 63 CALIF. L. REv. 375, 375-76 (1975) (challenging the "received legal model of corporate decisionmaking," in which the board manages the corporation). Nevertheless, subsequent scholarship observed that the prospect of effective vigilance by the board is often undermined by the ability of managers to influence the makeup and performance of the board. For discussions of the relationship between the board of directors and the managers, see generally, Brudney, supra; Eisenberg, supra; Kenneth E. Scott, Corporation Law and the American Law Institute Corporate Governance Project, 35 STAN. L. REv. 927 (1983). At least prior to the rise of large institutional equity investors, the shareholders of large corporations were too dispersed to impose any effective counterweight against the influence of managerial insiders. See Jayne W. Barnard, Institutional Investors and the New Corporate Governance, 69 N.C. L. Rev. 1135, 1149-50 (1991); Eugene F. Fama \& Michael C. Jensen, Separation of Ownership and Control, 26 J.L. \& EcoN. 301, 313-15 (1983). See generally Ronald J. Gilson \& Reinier Kraakman, Reinventing the Outside Director: An Agenda for Institutional Investors 43 StaN. L. REv. 863 (1991); Steven N. Kaplan \& David Reishus, Outside Directorships and Corporate Performance, 27 J. Fin. Econ. 389 (1990).

5. Outside directors often play a significant role in firm decisions. In many corporations, they are active members of board subcommittees that oversee audits, executive compensation, and nominations. They are assigned inereasingly important roles in reviewing transactions that raise conflicts of interest within the board. See generally AMERICAN LAW INSTITUTE, PRINCIPLES OF Corporate Governance: Analysis and Recommendations, vol. 1, pts. III, V, VI (1994).

6. See generally Harry DeAngelo \& Linda DeAngelo, Proxy Contests and the Governance of Publicly Held Corporations, 23 J. Fn. Econ. 29 (1989).

7. Rule 14a-8 under the Securities Exchange Act of 1934, 17 C.F.R. $\$ 240.14 a-8$ (1994). See generally Lilli A. Gordon \& John Pound, Information, Ownership Structure, and Shareholder Voting: Evidence from Shareholder-Sponsored Corporate Governance Proposals, 48 J. FIN. 697 (1993).

8. See generally Frank H. Easterbrook \& Daniel R. Fischel, Contract and Fiduciary Duty, 36 J.L. \& ECON. 425 (1993). 
kets, ${ }^{9}$ capital markets (notably the market for corporate control), ${ }^{10}$ and product markets. ${ }^{11}$

During the $1980 \mathrm{~s}$, leveraged buyouts and takeovers acted as the predominant method of correcting managerial slack by removing managers who failed, for instance, to downsize operations in the face of excess capacity. By the end of the decade, managers and employees combined to implement takeover defenses, to challenge hostile takeover attempts in court and to lobby for antitakeover laws in state legislatures. ${ }^{12}$ These responses, coupled with the growing public apprehension over the leveraging of American corporations, brought about the demise of the takeover as a disciplinary device, leaving internal mechanisms to correct slack before product markets forced downsizmg or liquidation. To many observers, including Michael Jensen, these internal forces are too weak to force timely and efficient responses to excess capacity. ${ }^{13}$ The current hope lies in the emergence of sophisticated investors who hold large equity stakes in corporations and consequently both the ability and the incentives to pressure boards of directors to discipline their managers. ${ }^{14}$

The typical model of corporate governance generally views managerial agency problens through the lens of equity interests. ${ }^{15}$ Shareholders play

9. See Eugene F. Fama, Agency Problems and the Theory of the Firm, 88 J. PoL. Econ. 288, 293 (1980); Ronald J. Gilson, A Structural Approach to Corporations: The Case Against Defensive Tactics in Tender Offers, 33 Stan. L. Rev. 819, 838-40 (1981).

10. See Henry G. Manne, Mergers and the Market for Corporate Control, 73 J. Pol. Econ. 110 (1965). During the 1980s, takeovers were facilitated by the availability of high-yield (junk) bond financing, and the resulting market for corporate control was heralded by some as the most potent constraint on managerial conduct. See, e.g., Frank H. Easterbrook \& Daniel R. Fischel, The Proper Role of a Target's Management in Responding to a Tender Offer, 94 HARV. L. REv. 1161, 1168-73 (1981) (describing tender offers as one method of monitoring managerial behavior); Roberta Romano, $A$ Guide to Takeovers: Theory, Evidence, and Regulation, 9 YALE J. ON REG. 119, 129-31 (1992) (discussing how takeovers discipline managerial misbehavior). The intensity of the takeover threat drove management (allied with other stakeholder groups) to prevail directly on the political process and indirectly on the judiciary to constrain its force. For an account of the demise of the takeover instrument, see Jeffery N. Gordon, Corporations, Markets, and Courts, 9l CoLum. L. Rev. 1931 (1991) (chronicling the events surrounding Paramount Communications, Inc. v. Time Inc., 571 A.2d 1140 (Del. 1989)).

11. See Ralph K. Winter, Government and the Corporation 20-21 (1978); Fama, supra notc 9, at 289; Michael C. Jensen \& William H. Meckling, Theory of the Firm: Managerial Behavior, Agency Costs and Ownership Structure, 3 J. Fin. Econ. 305, 327-30 (1976).

12. See generally Gordon, supra note 10.

13. Jensen, supra note 3 , at $852-62$ (providing anecdotal and quantitative evidence of failure of internal control systems).

14. See, e.g., Barnard, supra note 4; Bernard S. Black, Shareholder Passivity Reexamined, 89 Mich. L. REv. 520, 567-75 (1990); Edward B. Rock, The Logic and (Uncertain) Significance of Institutional Shareholder Activism, 79 GEO. L.J. 445, 447-53 (1991); Andrei Shleifer \& Robert W. Vishny, Large Shareholders and Corporate Control, 94 J. Pot. Econ. 461, $465-71$ (1986).

15. While corporate governance scholarship has responded to the Berle and Means concern over diffuse shareholder voting rights, it remains focused to a large degree on mechanisms that rely on the initiative of equity investors: for example, the election of outside directors, derivative suits, and takeover bids. For instance, Ronald Gilson and Reinier Kraakman comment on the marginal rolc of banks in American corporate governance: 
the central role in the internal disciplinary mechanisms identified above. They vote for directors, engage in proxy contests, present shareholder proposals, and sue to enforce fiduciary duties owed to the firm. In addition, the market for corporate control is a market for equity interests. There is, however, a distinct body of literature that examines the screening and monitoring activities of debtholders. It has evolved separately because it is largely unconcerned with the self-interested behavior of managers. Instead, it assumes that managers are perfect agents of their shareholders and focuses on the conflict between debtholders and equityholders. This literature, for example, explains lending through financial intermediaries as delegated monitoring: the intermediary pools money from investors, lends it, and monitors on their behalf. ${ }^{16}$ Intermediation resolves the problems of freeriding and duplicative inonitoring efforts. Moreover, the intermediary itself typically enjoys information-producing economies that make it a superior screening and monitoring agent. ${ }^{17}$ The role of the bank in particular as a delegated inonitor for its depositors is well established in the literature. ${ }^{18}$

Beyond the delegation of monitoring responsibility by investors to internediaries, there is a growing awareness of the interdependencies among various debtholders of a given firm. A creditor's monitoring activities produce positive and negative externalities for other creditors. ${ }^{19}$ If a creditor's momitoring deters borrower mishandling, it reduces the risk on all

By restricting the size of banks and the scope and geographical range of their activities, the regulatory web enveloping the American financial services industry has tightly restricted bank influence. Neither their credit provision function nor their limited equity ownership provide banks with sufficient power and incentive to monitor.

As a result, the monitoring role in the American corporate governance system is relegated to those who provide only equity capital to the corporation-the shareholders.

Ronald J. Gilson \& Reinier Kraakman, Investment Companies as Guardian Shareholders: The Place of MSIC in the Corporate Governance -Debate, 45 STAN L. REv. 985, 989-90 (1993) (footnote omitted).

16. See, e.g., Douglas W. Diamond, Financial Intermediation and Delegated Monitoring, 51 REv. ECON. Stud. 393 (1984); Hayne E. Leland \& David H. Pyle, Informational Asymmetries, Financial Structure, and Financial Intermediation, 32 J. FiN. 371, 382-84 (1977) (identifying the signaling advantages of a lending intermediary).

17. See, e.g., Leland \& Pyle, supra note 16, at 371-72. Leland and Pyle suggest that financial intermediation solves the public good problem of information and, because the intermediary invests some of its own capital, establishes the credibility of its information. Id. at 372; see also Eugene F. Fama, What's Different About Banks?, 15 J. MonetaRy Econ. 29, 36 (1985).

18. See, e.g., George J. Benston \& Clifford W. Smith, Jr., A Transactions Cost Approach to the Theory of Financial Intermediation, 31 J. FN. 215, 219, 223 (1976) (noting that banks are efficient in obtaining confidential information because they can easily acquire reputation for discretion); Fischer Black, Bank Funds Management in an Efficient Market, 2 J. FIN. Econ. 323, 326 (1975) (explaining that bank's record of borrower as depositor provides low-cost credit information); Tim S. Campbell, Optimal Investment Financing Decisions and the Value of Confidentiality, 14 J. Fin. \& QuaNtitative ANALYsis 913, 921 (1979) (describing duty of confidentiality imposed on banks); Tim S. Campbell \& William A. Kracaw, Information Production, Market Signalling, and the Theory of Financial Intermediation, 35 J. FIN. 863, 880 (1980) (argning that banks enjoy economies when they can jointly produce information, liquidity, or transactions services).

19. See Randal C. Picker, Security Interests, Misbehavior, and Common Pools, 59 U. CHI. L. Rev. 645, 657-60 (1992); George G. Triantis, Secured Debt Under Conditions of Imperfect Information, $21 \mathrm{~J}$. LEGAL STUD. 225, 241-45 (1992). 
the firm's debt. However, if a creditor monitors simply to detect misbehavior before any other creditor with competing claims, the other creditors are less likely to be paid after the monitoring creditor. ${ }^{20}$ Moreover, since the concerns about managerial slack are shared to some degree by all parties who contribute to the enterprise, interdependencies exist even across classes of stakeholders. ${ }^{21}$ The screening and momitoring activities of a lender produce externalities that benefit other creditors and other stakeholders.

These benefits are produced at several periods throughout the relationship between the lender and its borrower. First, the decision to lend signals to other stakeholders and potential stakeholders the quality of the borrower. ${ }^{22}$ Second, other stakeholders know that the imposition of fixed obligations under the loan agreement forces managers to disgorge free cash rather than use it to bankroll forms of managerial slack (for example, managerial perks or empire building). ${ }^{23}$ These obligations will also force management to raise funds for future projects in vigilant capital markets, rather than by drawing from a pool of available internal funds. ${ }^{24}$ Third, when the lender is given either a security interest in assets of the borrower or some other form of priority rights, these features constrain the ability of managers to liquidate non-cash assets or to raise new funds by selling debt in the future. The presence of free cash facilitates managerial slack. Therefore, by reducing the ability of management to liquidate assets, security interests and priority rights thereby reduce the risk of slack in a way that benefits other constituencies as well. ${ }^{25}$ Fourth, many loan covenants, and the lender's monitoring of the borrower's compliance with such covenants, forbid specific types of behavior by management, thus further constraining managerial slack.

Based on this understanding, a theory of interdependent screening and momitoring is evolving to describe externalities that flow not only among

20. Triantis, supra note 19 , at $242-43$ (comparing cooperative and competitive monitoring).

21. See generally Saul Levmore, Monitors and Freeriders in Commercial and Corporate Settings, 92 Y ALE L.J. 49 (1982). See also Barry E. Adler, An Equity-Agency Solution to the Bankruptcy-Priority Puzzle, 22 J. LeGal Stud. 73, 89-95 (1993); Joseph E. Stiglitz, Credit Markets and the Control of Capital, 17 J. MONEY, CREdIT, \& BankING 133, 140-45 (1985).

22. Fama, supra note 17, at 36-37 (identifying information and signals picked up by other stakeholders); Eugene F. Fama, Contract Costs and Financing Decisions, 63 J. Bus. S71, S84-86 (1990). Fama argues that the value of the bank's signal is greater if the bank holds unsecured debt. $I d$. at $\mathrm{S} 86$.

23. Michael C. Jensen, Agency Costs of Free Cash Flow, Corporate Finance, and Takeovers, 76 Am. Econ. Rev. 323, 324 (1986). If the firm fails to meet these obligations, the lenders can take steps to terminate the employment of the managers. See generally F.H. Buckley, The Termination Decision, 61 UMKC L. Rev. 243 (1992).

24. See Frank H. Easterbrook, Two Agency-Cost Explanations of Dividends, 74 AM. ECON. REv. 650,654 (1984) (noting that frequent trips to capital markets for funding results in close, effective monitoring of management); Jensen, supra note 23, at 323 (noting that internal financing avoids monitoring associated with debt sold in capital markets).

25. This argument is presented in George G. Triantis, A Free-Cash-Flow Theory of Secured Debt and Creditor Priorities, 80 VA. L. Rev. 2155, 2158-65 (1994). 
creditors, but also from lenders to other stakeholders, particularly shareholders. Our objective in this paper is to take the analysis to its next stage: a theory of interactive governance. We adopt a broad definition of "governance" that embraces the collective objective of firm value maximization and includes the activities of non-equity stakeholders. The governance activity of any individual stakeholder may be disaggregated into two constituent parts: monitoring and reaction. Monitoring involves the ongoing acquisition, processing, mterpretation, and verification of information about the firm. ${ }^{26}$ Reaction is the action taken when information culled from the monitoring process reveals an undesirable state of affairs. In his classic treatise, Albert Hirschman divided reaction into two types of action: exit and voice. ${ }^{27}$ Exit is the termination of one's relationship with the corporation following the detection of slack. Hence, a lender calls its loan, a shareholder sells her interest, a supplier ceases delivery, a customer switches to a competitor, or an employee quits. In contrast, voice is a deliberate attempt to correct, rather than to escape from, an objectionable state of affairs. ${ }^{28}$

Our theory of interactive corporate governance is based on two premises. First, all stakeholders share a common goal of constraining managerial slack that is only partly offset by the conflicts of imterest among stakeholders. In other words, the governance activities of one stakeholder generally yield positive net externalities to others. Second, through their observable reactions, stakeholders convey signals and information regarding the corporation to each other. Each stakeholder has a distinct window through which it observes the activities of the firm and each enjoys its own set of alternative reactions when it detects an undesirable state of affairs. The reactions of a stakeholder are im many cases observable by others who will in turn choose among their own set of available reactions. ${ }^{29}$ Thus, governance in the inodern corporation is akin to a system of relays: stakeholders generate, collect, and analyze valuable information on managerial slack, and then pass it to those stakeholders who are better situated to take direct action to address the problem. Under the theory of interactive corporate governance, this system of interstakeholder signals permits information gathered by dispersed stakeholders with concentrated expertise and hetero-

26. For a discussion of these mechanisms in the context of securities markets, see, e.g., Ronald J. Gilson \& Reinier H. Kraakman, The Mechanisms of Market Efficiency, 70 VA. L. REv. 549, 565, 59495 (1984).

27. Hirschman, supra note 2 , at 3-4.

28. Id. at 30. The mechanisms that effect change inside the corporation in response to external pressures are the subject of an increasingly sophisticated body of literature and should ultimately be incorporated into the study of corporate governance. See, e.g., HARVEY LEIBENSTEIN, INSIDE THE FIRM: THE lNEFFICIENCIES OF HIERARCHY (1987) (discussing decision-making within hierarchical internal structure). For the purposes of this paper, however, these mechanisms operate within a black box that responds to pressures crcated by the interactive governance of corporate stakeholders.

29. See Levmore, supra note 21 , at 69-72, 74-75 (arguing that the failure of a firm to pay a dividend to preferred shareholders and enforcement by secured creditors communicates valuable information to common shareholders). 
geneous perspectives on the firm's affairs to be communicated to those stakeholders best able to correct the managerial slack. It is this interaction among stakeholders who share governance responsibilities that distinguishes our theory from interdependent government theories that envision crisp delegations of responsibility. ${ }^{30}$ In this sense, the interactive theory is true to the contractual vision of the firm and yields a system that is in fact far more effective in disciplining and correcting managerial slack than the traditionally conceived model in which shareholders act as the sole principals for management.

In an effort to broaden the focus of American corporate governance away from equityholders, we begin by demonstrating the role of debt in interactive governance. In particular, we examine the role of debt through the activities of a familiar institution: the commercial bank. As noted above, the screening and monitoring skills of banks are well appreciated in the literature. However, in the view of many governance scholars, the effectiveness of the American commercial bank is impaired by the inhcrent governance limitations of its financial instrument-debt-which is viewed as excessively rigid compared to the nuanced governance tools of equity. ${ }^{31}$ For this reason, some commentators argue that the regulatory restrictions on equity holdings by banks prevent them from serving meaningful governance roles. ${ }^{32}$

We argue that debt is a potent and flexible governance instrument and that banks are effective governance players. Other stakeholders benefit not only from the ability of banks to deter and detect managerial slack by monitoring, but also from the actions taken by banks following the detection of slack. A bank may respond by scaling down or terminating its relations with the borrower (exit). Alternatively, the bank may use its threat of exit to intervene in the decisions of the firm (voice). It may be tempting to think that the bank plays a significant governance role only by exercising voice and not when it abandons ship. For this reason, we are more intrigued by the impact of bank exit on governance. The bank's exit may send an early signal to other stakeholders that prompts thein to act earlier than they might have otherwise in order to correct slack. ${ }^{33}$ The value of exit is a unique

30. See infra text accompanying note 131 .

31. See, e.g., Gilson \& Kraakman, supra note 15, at 989-90; Oliver E. Williamson, Corporate Finance and Corporate Governance, 43 J. Fin. 567, 579-81 (1988).

32. In this respect it is interesting that in some jurisdictions where such restrictions are absent, banks do not hold stock in their borrowers to the full extent allowed by law. See Bernard S. Black \& John C. Coffce, Jr., Hail Britannia?: Institutional Investor Behavior Under Limited Regulation, 92 Mich. L. REv. 1997, 2074 (1994) (with respect to the U.K.); Ronald J. Daniels \& Paul Halpern, The Canadian Quandary: Accounting for the Survival of the Closely Held Corporation, 25 CAN. Bus. L.J. (forthcoming 1995) (with respect to Canada).

33. See generally Eli Ofek, Capital Structure and Firm Response to Poor Performance, 34 J. Fin. EcoN. 3 (1993) (providing empirical support for proposition that highly leveraged firms respond earlier to declines in firm value). 
insight of the interactive theory and it offers new explanations for contractual terms and legal rules that affect the ability to exit.

In Part II, we discuss how several contractual and legal mechanisms are structured to enhance the effectiveness of the signal that a bank's exit sends to other stakeholders. We thereby suggest new motivations for debt covenants and bankruptcy preference rules that have been missed in existing scholarship and are illuminated by our theory of interactive corporate governance. In particular, covenants and events of default typically define the start of a bank's contractual right to exit. Bankruptcy law provisions such as voidable preference rules and the automatic stay shut down this right when the borrower becomes insolvent. Thus, the window of opportunity for bank exit is defined by contract (covenants) and by statute (bankruptcy law) to correspond to the period during which the signal sent by exit is most valuable.

As stated above, one of the fundamental assumptions underlying the theory of interactive corporate governance is that all stakeholders share the goal of firm-value maximization. Even if all stakeholders do share a concern about managerial slack, their interests sometimes diverge, particularly as the firm's financial condition deteriorates. This divergence provides an explanation for the existence of rules that prevent one stakeholder from benefiting at another stakeholder's expense in situations where it is likely that conflicts of interests among stakeholders outweigh the benefits arising from the signals sent by stakeholder action. In reacting to slack, an active stakeholder's voice will reflect a self-interested bias. Thus, a bank may use its threat of exit or its voice not only to redress slack, but also to obtain a favorable renegotiation of the lending terms (for example, additional collateral).

As we discuss in Part II, a lender who is perceived to control its borrower's decision-making and to have improved its position relative to other creditors may not be permitted by law to realize such gains in a subsequent exit. In contrast, despite the known bias of lenders in favor of conservative strategies that may not be value-maximizing, the courts are prepared to permit the exercise of bank voice to influence firm decisions. We suggest that this judicial restraint is desirable because, in many cases, the net benefit of bank voice is positive, relative to the alternatives of leaving or moving control into the hands of other stakeholders. Moreover, the exercise of bank voice prior to the firm's insolvency sends timely signals to other stakeholders who may then react to correct any slack.

In Part III, we generalize the analysis of interactive governance across a broader range of constituencies. Viewed across all stakeholders, the interactive theory leads to a deeper understanding of the organizational strength of American corporate governance. It is a process that is triggered by the early detection of managerial slack in any of the far reaches of the corporation. The information is passed through exit (and sometimes voice) signals 
to sophisticated stakeholders with the ability to take action to correct the slack. $^{34}$ With the aid of two short case studies, we explore the channels by which signals are communicated among stakeholders and the mechanisms that evolve to decode signals that are unclear, often because they have been clouded by competing interpretations offered by management. Finally, our Conclusion suggests that further inquiry into the quantity and quality of governance signals would contribute significantly to our understanding of interactive corporate governance.

\section{I \\ The Role of Debt In the Interactive Governance Process}

As a governance mechanisn, debt offers potent and flexible levers over managerial decisions. Bank lenders provide the bulk of financing for small- and medium-sized firms. As a result, they enjoy significant monitoring advantages over other stakeholders and can use their governance levers to play the principal role in controlling managerial slack. ${ }^{35}$ The other stakeholders, particularly creditors, benefit from the bank's active voice in management decisions and, to a large degrce, they depend on it. The dominance of bank lenders and the correlative dependency of other stakeholders on the bank is diluted substantially in larger, public corporations, which are characterized by a more complex web of interactive stakeholder monitoring and reaction functions. In this environment, a bank typically exercises less voice in management but its exit provides a valuable contribution to corporate governance. As a first step toward understanding the governance instruments and interactive roles of stakeholders other than shareholders, this Part presents a stylized thcory of the activities of bank lenders in public corporations. As the Introduction states, the key to under-

34. Our interactive governance theory identifies the value of exit, but leavcs a host of interesting questions to be addressed by future analysis. A fundamental question is whether exit signals will tend to be under- or over-supplied relative to an optimum. For example, employers and employees may try to suppress or camouflage the real reason for the termination of an employment relationsbip, as may trade creditors or banks and their debtors. In contrast, an employee, trade creditor, or bank may threaten to exit publicly in order to extract more favorable terms from the firm. In order to make such a threat credible, the stakeholder may have to carry it out on occasion. These are questions we touch on in Part III to suggest several legal and institutional mechanisms that are evolving to enhance the effectiveness of exit signals in corporate govemance. However, as we acknowledge in the Conclusion, we leave much of the analysis and institutional research to later work.

35. Robert Scott presents a govemance model for young, expanding owner-operated firms that obtain most of their eapital from relational financers (typically banks), in which the financers take broad security interests in order to enhance their leverage over their borrowers' decisions. Robert E. Scott, $A$ Relational Theory of Secured Financing, 86 ColuM. L. Rev. 901 (1986). The banks act as police who walk the beat for the benefit of other creditors of their borrowers. Id. at 931 . We extend Scott's thesis to argue (1) that the beneficial monitoring and reaction activities of banks are also present, though perhaps less directly, in firms with both debt and outside equity investors, and (2) that banks can perform valuable governance functions even by terminating their relations with the firm. 
standing interactive governance is to appreciate the value of exit under various circumstances.

Large corporations with good reputations rely less on bank lending for short- and medium-term debt capital and issue instead debt instruments such as commercial paper and medium-term notes. ${ }^{36}$ This trend is viewed by some as the eclipse of bank lending (other than to small businesses). ${ }^{37}$ Nevertheless, even the largest firms do not rely exclusively on public capital markets. Banks provide cash manageinent and transaction services for these firms. Moreover, although the inarket for high-yield, high-risk bonds is vibrant once again, virtually all commercial paper continues to be investment grade. ${ }^{38}$ Therefore, issuers often need to back their commercial paper with lines of credit from banks. In addition, bank lines of credit provide liquidity insurance to the issuer in the event it cannot roll over its commercial paper upon maturity because, for instance, of a credit rating downgrade. ${ }^{39}$ The issuer can rely on its relationship with its bank to secure new financing without having to incur the cost (both out-of-pocket and delay in time) of recertifying its credit worthiness to a new bank.

Banks enjoy well-known monitoring advantages listed below, of which the latter two are more idiosyncratic to banks. First, by lending to a number of different firms in the saine industry or region, banks develop a broadly based benchmark against which to evaluate the performance of each borrower. Second, banks usually lend short- or medium-term in order to match assets with their principally short-term liabilities. The periodic renewals of credit agreements provide opportunities for the acquisition and assessment of new information about the condition of the firm. ${ }^{40}$ Third, banks are able to exploit economies of scope in the nonitoring process by also providing transaction and cash management services to the borrower. A borrower is often required to keep compensating balances in a current account with its bank lendcr. By inspecting the borrower's current account outflows and

36. See, e.g., Allen N. Berger \& Gregory F. Udell, Securitization, Risk, and the Liquidity Problem in Banking, in Structural Change IN Bankng 227, 232 (Michael Klausner \& Lawrence White eds., 1993).

37. See, e.g., Douglas W. Diamond, Monitoring and Reputation: The Choice Between Bank Loans and Directly Placed Debt, 99 J. PoL. EcoN. 689, 713 (1991) (concluding that firms with good credit ratings can lower their cost of capital by borrowing directly in public debt markets).

38. See Calvin D. Schnure, Debt Maturity Choice and Risk-Free Assets: The "Clientele Effect" and the Commercial Paper Market, Finance And Economics Discussion Series, No. 94-4 (Federal Reserve Board, Washington, D.C.), April 1994, at 5-9.

39. For example, in light of the downgrading of its debt in 1993, General Motors Corporation increased its available bank lines of credit as a financial cushion in the event that it would not be able to either place enough new securities or renew the more than $\$ 20$ billion in debt coming due that year. Steven Lipin \& Douglas Lavin, GM Seeking \$24.75 Billion Credit Line: 17 Banks Are Likely to Commit Funds, WaLl St. J., March 11, 1993, at A4.

40. Mitchell Berlin, Bank Loans and Marketable Securities: How Do Financial Contracts Control Borrowing Firms?, Bus. Rev., Fed. Reserve Bank of Philadelphia, July-Aug. 1987, at 9; Christopher James \& Peggy Wier, Are Bank Loans Different?: Some Evidence From the Stock Market, J. APpLIED CORP. Fin., Summer 1988, at 46, 52-53. 
inflows, the bank can learn both the identity of and levels of payments to customers, suppliers, and employees. ${ }^{41}$ In this way, the bank can react upon its discovery of delays and difficulties with the payments to or from any of these constituents. ${ }^{42}$ Fourth, the documentation supporting bank debt requires the borrower to supply periodic information to assist the bank in policing compliance with the typically extensive debt covenants (which we discuss below). Moreover, a borrower usually undertakes to advise the bank of any violation of its covenants. This communication is likely to be more timely than public disclosure required under securities laws, ${ }^{43}$ largely because banks are bound to adhere to the legal duty of confidentiality. ${ }^{44}$ This duty allows a borrower to provide valuable confidential information to banks without fearing that it will be leaked to industry competitors. ${ }^{45}$ In marked contrast, a borrower is much more reluctant to release information to public debt investors and equity investors owing to the difficulties of controlling the dissemination of such information. ${ }^{46}$

To be an effective player in corporate governance, a bank must not only monitor the corporation, but it must also be able to act on the information it acquires. One action a lender can take is to exit. A lender has several means of exit from the corporate enterprise. It can limit its investment in the borrower by refusing to provide additional financing or to make future advances under existing credit facilities. It can also accelerate the maturity of the outstanding debt, refuse to renew existing debt, and, if necessary, enforce its matured claim against the borrower's assets.

41. See Black, supra note 18, at 326 (noting information advantages of banks); Fama, supra note 17 , at 35-38 (same).

42. Jonathan Macey and Geoffrey Miller argue that this advantage of bank monitoring is being steadily eroded by technological innovation in monitoring processes and the rise of more cost-effective independent data-processing services. Jonathan R. Macey \& Geoffrey P. Miller, Bank Failure: The Politicization of a Social Problem, 45 Stan. L. Rev. 289, 294-95 (1992) (book review). As a result, thc position of banks in the interactive governance of public corporations may be in flux and what we define as the bank's role may soon be assumed by other stakeholders.

43. See infra note 53. Although the disclosure obligation under securities law requires management to release information on a timely basis, management enjoys considcrable latitude in determining when the information is ripe enough to be released. See generally Rohert E. Verrecchia, Discretionary Disclosure, 5 J. Acct. \& EcoN. 179 (1983) (positing that managerial discretion in disclosure is a function of disclosure cost).

44. The common law duty of confidentiality that banks owe to customers was enunciated in Toumier v. National Provincial \& Union Bank of England, 1 K.B. 461, 480 (1924) (noting that implicd term of bank's contract with its customers is that bank will not divulge information concerning customer's accounts to third parties). On the importance of the confidentiality feature to the role of banks as a financial intermediary, see Benston \& Smith, supra note 18, at 219-23; Campbell, supra note 18 , at 921 .

45. The confidentiality restriction, however, may impede somewhat the communication of information necessary to clarify signals in an interactive model.

46. See Frank H. Easterbrook \& Daniel R. Fischel, The Economic Structure of CORPORATE LAW 290-92 (1991) (discussing appropriability problems related to relcase of firm-specific information). For concerns of confidentiality, see also Campell, supra note 18, at 920-21. 
Bank exit creates a sense of urgency among management and the board of directors that motivates corrective action. ${ }^{47}$ The impact of bank exit upon management is a function of the amount of indebtedness to the bank and the abruptness of the bank's exit. To be effective, the consequences of exit must be strong enough to deter slack ex ante or to induce correction ex post, but not so devastating as to eliminate any opportunity for change. ${ }^{48}$ In some cases, even repentant managers have difficulty finding new financing for their firm after the withdrawal of their main bank. Moreover, if the bank's exit is observable outside the circles of the firm's management and the board, it may prompt similar exit by other creditors. ${ }^{49}$ This situation may precipitate the firm's collapse before management has the opportunity to remedy the performance lapse.

However, several factors reduce the risk of such a collapse. First, borrowers reduce their vulnerability to bank exit to some extent by diversifying away from bank financing. Second, as we discuss later, the laws of voidable preferences and the bankruptcy stay on creditor enforcement encourage early exit. Third, an expanding group of sophisticated investors specialize in lending to troubled enterprises and purchasing distressed debt securities. $^{50}$ Fourth, the availability of Chapter 11 bankruptey proceedings offers management a way to forestall the collapse and correct its slack under the close scrutimy of its creditors and the bankruptcy court. ${ }^{51}$

Although exit is an attractive option for those stakeholders for whom exit entails low cost, not all stakeholders will choose to or be able to exit. Thus, exit by some stakeholders may induce the remaining or new stakeholders to exercise voice instead. Exit is more costly for stakeholders who have made significant relation-specific investments. These stakeholders may provide the financial support for the continuation of the firm and the lender's exit may be the catalyst for their intervention in the governance of the firm. The bank's exit may also prompt institutional shareholders to intervene if their exit is constramed by the size of their investments. A

47. In a similar vein, Michael Jensen refers to debt as a "powerful agent for change" because, if managers cannot meet their interest obligations out of the firm's cash flow, they are forced to rethink their strategy and structure. Michael C. Jensen, Eclipse of the Public Corporation, Harv. Bus. REv., Sept.-Oct. 1989, at 61, 67; see also Karen H. Wruck, Financial Distress, Reorganization, and Organizational Efficiency, 27 J. FIN. EcoN. 419, 430-35 (1990) (analyzing the effect of financial distress on organizational efficiency). The tendency of boards to become more activist when the corporation is perceived to be in crisis is well established in the empirical literature describing board behavior. See, e.g., Jay W. Lorsch, Pawns or Potentates: The Realtry of AMerica's Corporate Boards, 141-67 (1989); Myles L. Mace, Directors: Myth and Reality 27-39 (1971).

48. HirSCHMAN, supra note 2, at 22-25.

49. Many debt instruments have clauses which trigger default if the borrower defaults under any other debt contract (cross-default clauses). In addition, a public company may have to report significant defaults as a material change under its securities law disclosure obligation. See infra note 53.

50. See, e.g., Edward I. Altman, Distressed Securties: Analyzing and Evaluating Market Potential and Investment Risk (1991).

51. See infra note 116 and accompanying text. 
bank's exit is often a highly observable signal of managerial slack. ${ }^{52}$ Public corporations are required by securities laws to disclose most instances of exit by a prominent lender. ${ }^{53}$ As suggested above, the bank's exit may prompt some existing shareholders for whom exit is difficult to intervene in the management of the firm. ${ }^{54}$ On the other hand, a borrower's smaller shareholders for whom exit is less costly may respond to bank exit by selling their interests in security markets. However, their exit creates incentives for entry by new shareholders who are skilled and willing to intervene to correct the slack in the firm's performance. ${ }^{55}$ Similarly, the bank's exit provides an opportunity for another lender to step in. A lender with expertise in rehabilitating deteriorating enterprises may be attracted by the pre-

52. The transfer of information may also work in the opposite direction. Jamcs Booth provides empirical evidence that the cost of bank loans is lower when there is public trading of shares in the borrower. He claims that this is the result of the information produeed by the observable prices from the market trades, reports by securities analysts, filing requirements, audits, and public announccments. Booth also finds that the cost of bank borrowing is reduced if the firm has rated, investment-grade public debt outstanding, particularly if the public debt is of lower priority. He attributes this reduction in cost to the monitoring and information produced by bond-rating agencies. James R. Booth, Contract Costs, Bank Loans, and the Cross-Monitoring Hypothesis, 31 J. Fin. Econ. 25, 27-28, 36-41 (1992).

53. The duty to disclose changes in the issuer's banking arrangements derives from a number of different sources. Under $\S 13(\mathrm{a})$ of the Securities Exchange Act of 1934, 15 U.S.C. $\$ 78 \mathrm{~m}$ (1994), the Securities and Exchange Commission is entitled to require issuers to make such filings as are "necessary or appropriate for the proper protection of investors and to insure fair dealing in the security." 15 U.S.C. $\S 78 \mathrm{~m}(\mathrm{a})$ (1994). Pursuant to this authority, the Commission requires issuers to file with it periodic (annual and quarterly) forms detailing the financial status of the issuer and, where appropriate, Form 8$\mathrm{K}$ reports that advise investors of current changes. Dennis J. Block et al., Affirmative Duty to Disclose Material Information Concerning Issuer's Financial Condition and Business Plans, 40 Bus. LAw. 1243, 1244-48 (1985). Apart from these explicit reporting requirements, issuers are also required to disclose information to investors pursuant to the anti-fraud rules set out in Rule 10b-5. Id. at 1248-55. In tandem, these requirements have been interpreted by the Commission as requiring "full and prompt announcements of material facts regarding the company's financial condition." Timely Disclosure of Material Corporate Developments, Exchange Act Release No. 34-8995, 35 Fed. Reg. 16,733 (Oct. 29, 1970). Finally, stock exchange listing requirements stipulate that issuers must make timely disclosure. Block, supra, at 1255-57. Block notes, for example, that the ASE guidelines require "immediate public disclosure of all material information." Id. at 1255-56 (citing American Stock Exchange Company Guide $\S 401$ (a), reprinted in 2 Fed. Sec. L. Rep. (CCH) I 23,124A, at 17,097-98). For a general discussion of the scope of the securities disclosure obligation, see Block, supra, at 1243-57.

Discussions with officials at the American and New York exchanges confirmed that pursuant to these obligations issuers routinely disclose to the public changes in banking arrangements, including defaults (both technical and material), terminations of or revisions to existing credit arrangements, and, where substantial, entry into new banking relationships.

54. Levmore describes how secured creditors in particular serve this function:

Secured creditors that monitor their collateralized assets can provide "signals" about the

financial stability of the firm to its outside shareholders. . . . Shareholders (or directors) beset

by monitoring difficulties will, for example, find it relatively easy to note instanccs of judieial

foreclosure, repossession or disposition of collateral.

Levmore, supra note 21 , at 69-70 (footnotes omitted).

55. This entry by "skilled" shareholders may explain the empirieal observation by Gilson that financial distress is accompanied by an increase in the proportion of common stock held by blockholders (defined as investors holding stakes of at least $5 \%$ ), who consolidate outstanding shares. Stuart $\mathrm{C}$. Gilson, Bankruptcy, Boards, Banks, and Blockholders, 27 J. FIN. Econ. 355, 379-84 (1990). There is also typieally an increase in the percentage of outside board seats held by these blockholders. Id. at 370-79. 
mium it will receive for turning around the firm. In sum, bank exit may provide the stimulus for constructive change either directly by its immediate impact on management and the board, or indirectly by inducing the exercise of voice by other stakeholders.

A bank that detects managerial slack will not always choose to exit. Instead, the bank may defer exit and use the threat of exit as a lever to intervene in the firm's decisions. The leverage confers considerable discretion on the bank in its exercise of voice. ${ }^{56}$ The bank's choice between exit and voice is based on a self-interested evaluation of the relative net benefits from each option. A bank that exits enjoys the benefit of a more certain recovery of its investment. However, it bears transaction and regulatory costs of exit, ${ }^{57}$ incurs search and transaction costs in entering into new lending arrangements, and may forgo the opportunity to finance a revitalized borrower in the future. In addition, bank management may be reluctant to abandon a sunk investment, even if a prospective cost-benefit calculation favors exit. s $^{58}$

On the other side of the ledger, the gains from voice are a function of the ability to influence management and thereby improve firm performance. In exercising its voice, the bank can draw on expertise and inforination acquired in the monitoring stage. In addition, it may hold sufficient debt to have an incentive to intervene on its own without facing the obstacles to collective action that impede the exercise of governance rights by other diffuse stakeholder groups. In particular, whereas dispersed shareholders may be unable to disciplme management effectively through their voting rights, a bank with a large enough investment will have sufficient incentive to intervene effectively. Most significantly, as a debtholder, the bank has a very credible exit threat which gives it leverage over the borrower's decisions. However, the relatively low cost of exit that makes the bank threat credible also reduces the bank's incentive to postpone exit and exercise voice. ${ }^{59}$ Therefore, the bank's self-interest may dictate exit even in circum-

56. See Alexander J. Triantis \& George G. Triantis, Conversion Rights and the Design of Financial Contracts, 72 WASh. U. L.Q. 1231, 1252-54 (1994). Compare Oliver Williamson's comment that debt imposes a rule-governed regime, in contrast to the more adaptable controls of equity. Williamson, supra note 31 , at 580-81 (arguing that "equity is more forgiving than debt"). Williamson understates the potential in debt for nuanced governance, given the discretion of the lender in extending financing, renewing credit, or accelerating maturity.

57. For instance, when a bank calls a loan, it attracts the attention of regulators and may be forced to accept a write-down of its assets that, in turn, impacts on its capital base. For discussion of capitaladequacy regulation, see Jonathan R. Macey \& Geoffrey P. Miller, Banking Law and Regulation 284-87 (1992).

58. See generally AllaN 1. Teger, TOO Much INVEsted to Quit (1980) (describing psychology of conflict escalation); Glen Whyte, Escalating Commitment to a Course of Action: A Reinterpretation, 11 ACAD. MGMr. REv. 311 (1986) (analyzing aitemative explanations for escalating commitments to losing courses of action).

59. Hirschman observes that the availability of an exit option reduces the willingness to develop and use the voice mechanism. Hirschman, supra note 2, at 44-54. Consider the following three examples. First, a lender with a security interest in real estate can enforce its debt with little difficulty. 
stances where its voice would be a more effective governance tool in correcting managerial slack. Nevertheless, as we note above, the bank's exit has value in prompting the intervention of other constituencies who may have a positive impact on firm performance.

In sum, bank momitoring and reaction may correct managerial slack either directly, by precipitating a crisis in the boardroom and exercising voice, or indirectly, by exiting and providing a signal for the intervention of others. ${ }^{60}$ The bank's multifaceted role in governance illuminates a variety of relations with other stakeholders that range from dependency to interaction. To be sure, not all stakeholders are active participants in the interactive process. Some rely on the actions of others to deter misbehavior and correct slack, and their relationship to active governance players is simply one of dependency. For example, consider investors in a firm's publicly issued debt. Public debt is issued under a trust indenture which contains the terms of the debt contract and appoints a trustee to represent the interests of the disparate debtholders. Despite the similarity in the default risks in bank and public debt, the typical covenant in public debt protects the debtholder to a much lesser degree than the typical covenant in commercial bank debt. ${ }^{61}$ In addition, the indentures often limit the responsibility of the trust-

Therefore, its dominant strategy is to exit when it detects an event of default that reflects deterioration in the firm's performance. Yet, the ease of exit also enhances the credibility of the secured lender's exit threat, which it might have used to induce profitable change in the management of the borrower. Second, an unsecured lender must invoke the relatively cumbersome mechanism of judicial debt enforcement in order to recover its investment. While this may deter the lender from exiting, it also deprives it of effective voice. As a final example, suppose the bank's debt is secured by a floating licn over inventory and accounts rcceivables. Inventory and receivables are usually marketable collateral and therefore the bank's exit is relatively easy. However, the credit an inventory or receivables lender extends will expand and contract with the business of the borrower. As a result, the lender who exits forgoes the opportunity to finance an expanding borrower should the problem of performance lapsc be corrected. Given this cost of exit, the intervention of the inventory or receivables financer is likely to be more effective than that of the unsecured lender and, at the same time, the former is also more likely than the real estate lender to postpone exit and intervene to correct managerial slack.

60. For instance, in his study of 300 publicly traded companies in the period 1974 to 1983, James found that stock prices reacted positively to announcements of bank debt-financing arrangements, while they fell upon announcements of other credit arrangements, notably public straight-debt offerings and privately placed debt. Christopher James, Some Evidence on the Uniqueness of Bank Loans, 19 J. Fin. EcoN. 217, 225-26, 231-34 (1987). While these results suggest that the activities of banks may benefit shareholders, they do not distinguish among, for example, the screening, monitoring, and governance roles of banks. In a subsequent article, Lummer and McConnell refined James' methodology to distinguish between the effects of announcements by banks of new and revised (including renewed) loan agreements. They found that most of the positive effects on share prices were due to favorable announcements of revisions of existing financing arrangements. On this basis, the authors conclude that the beneflt to shareholders is derived from the bank's access to private information aequired during its relationship with the borrower, rather than its advantage in screening the borrower at the time of the initial financing. Scott L. Lummer \& John J. McConnell, Further Evidence on the Bank Lending Process and the Capital-Market Response to Bank Loan Agreements, 25 J. Fin. Econ. 99, 120-21 (1989).

61. See Robert M. Lloyd, Financial Covenants in Commercial Loan Documentation: Uses and Limitations, 58 TENN. L. Rev. 335, 338-39 n.12 (1991) (listing three possible explanations for the lesser protections acquired by public debt holders); Martin Riger, The Trust Indenture as Bargained Contract: 
ees to monitor the lender's compliance with even the few covenants that are present. $^{62}$ Both the weakness of covenant patterns and the passivity of trustees is well known. However, a satisfactory explanation of the disparity in this respect between public debt and bank debt has eluded commentators because they have neglected to consider the interdependency between banks and public debtholders in corporate governance. ${ }^{63}$

Suppose a firm has a bank lender and public debtholders who are represented by their trustee. To keep the problem simple, assume that the bank debt and publicly issued debt have the same principal amount, maturity, and liquidation priority. To the extent that the covenants and momitoring of one lender deter misbehavior by the borrower, they benefit all debtholders. Therefore, if the bank knows that the trustee is monitoring, the bank will not duplicate the trustee's monitoring activity because its action would be of no additional value in deterring misbehavior, and vice versa. We assume for the moment that monitoring is a homogeneous activity im that the parties share the same perspective on the firm. Then, in equilibrium, only one of the two parties will engage im momitoring. ${ }^{64}$ However, while the equilibrium involves single-creditor momitoring, which creditor will monitor is indeterminate. The identity of the monitoring creditor is important whenever the two creditors' monitoring costs differ. The lower-cost monitor should engage in the monitoring activity. As a result of the informational advantages described above, ${ }^{65}$ banks are usually lower-cost monitors than indenture trustees, even when the latter are departments within banks. ${ }^{66}$ If bank-monitoring equilibrium is obviously preferable to trustee monitoring,

The Persistence of Myth, $16 \mathrm{~J}$. CoRP. L. 211 (1991) (chronicling the competing interests that create the relatively poor protection of public debtholders).

62. See Riger, supra note 61 , at $218-19$ and n.38. The passivity of trustees was also one of the subjects of inquiry by the Douglas Committee in the mid-1930s. See Securities and Exchange Commission, Report on the Study and lnvestigation of the Work, Activities, Personnel and Functions of Protective and Reorganization Committees, pt. VI (June 18, 1936) (hereinafter SEC REPORT).

63. Commentators have provided several explanations. First, indenture terms are settled between the issuer and the underwriter, neither of whom has any financial or lcgal interest to insert extensive covenants for the benefit of future holders of the securities. See, e.g., SEC REPORT, supra note 62, at 56, 9-10; Riger, supra note 61, at 218-19 (noting that the trustee's duty to protect shareholder interest only arises upon default). Second, the relative financial stability of the largest borrowers between the mid-1970s and mid-1980s lulled investors into a false sense of security. See, e.g., William W. Bratton, Jr., Corporate Debt Relationships: Legal Theory in a Time of Restructuring, 1989 Duke L.J. 92, 14142. Third, institutional investors shifted their investment policy from a buy-and-hold to a trading strategy and thereby became indifferent to the underlying nature of contractual protections. See, e.g., Richard Brook, Debt Covenants and Event Risk: The Practitioner as a Source of Evidence, Columbia Center for Law and Economics Studies Working Paper No. 51 (1990).

64. The two Nash equilibria are the bank monitors and the trustee does not, and vice versa. See generally Picker, supra note 19, at 664-69 (1992) (recognizing that any situation where both or neither monitored would be unstable); Alan Schwartz, The Continuing Puzzle of Secured Debt, 37 VAND. L. Rev. 1051, 1056-57 (1984) (same).

65. See supra text accompanying notes $40-46$.

66. An additional advantage is arguably that the bank does not suffer from a collective-action problem in reacting to unfavorable information about the firm. The trustee is a fiduciary who typically 
the creditors themselves may focus on this equilibrium. ${ }^{67}$ Once it is reached there is no incentive to depart from it. Creditors pass on their monitoring costs to borrowers in the form of higher interest rates or fees. Given that borrowers bear the aggregate of their debtholders' monitoring costs, they will seek to ensure that the bank acts as monitor by appropriately structuring the terms of their debt contracts.

Debt issuers ensure that the bank does the monitoring, and not the trustee on behalf of public debtholders, by limiting the covenants and trustee obligations in public debt indentures. ${ }^{68}$ As a result, the bank knows that the trustee has few, if any, covenants to monitor and a diluted incentive to momitor due to the low standard of care. Therefore, the bank will carry out its monitormg function. To the extent that it deters borrower misbehavior, the bank's monitorimg inures to the benefit of public debtholders as well. In turn, the existence of a bank lender is a signal to debt investors that restrictive covenants are in place and that the firm's activities are being momitored. Therefore, they make a voluntary and fully informed decision to purchase debt instruments with limited covenant protection.

In the discussion thus far, we have argued that to the extent that lender momitoring, exit, and voice control managerial slack, these actions benefit all stakeholders. However, in other respects, the interests of the bank and other stakeholders diverge. In the economic model of the corporation, financial agency problems exist because, as agents of their shareholders, managers have incentives to make decisions that transfer wealth from debtholders to shareholders. Indeed, the exit rights of debtholders deter this type of borrower inisbehavior. To the extent that managers respond to bank influence, however, the bank is, in turn, an imperfect agent of the other stakeholders. Although it contributes to the correction of managerial slack, the bank also has incentives to use its considerable monitoring advantage and its leverage over firm decisions to enhance its position at the expense of other stakeholders.

In the remainder of this Part, we review four types of bank actions that produce interstakeholder conflict. First, the bank niay exit early for reasons unrelated to managerial slack: for instance, to escape an unfavorable deal with the borrower. Second, the bank may be lax in its monitoring and react too late to evidence of slack. Third, when the bank detects a deterioration in the borrower's financial condition, the bank may use its exit threat to improve the terms of its debt. Fourth, the bank may intervene to correct slack but, at the same time, may also inprint its own preferences on the

must wait for instructions from a vote of debtholders. However, there seems to be no obstacle to a trustee being given discretion to make the reaction decision without consulting the debtholders.

67. See David M. Kreps, A Course in Microeconomic Theory 410-17 (1990).

68. This theory presents an altemative to Randal Picker's proposal that the indeterminacy of Nash equilibria in a two-creditor monitoring subgame may be resolved by awarding contingent monitoring payments to one creditor, so that the designated creditor is compensated only for the monitoring costs that it actually incurs. Picker, supra note 19, at 664-69. 
business decisions of the firm. The agency costs in each of the four categories are often outweighed by the benefits of the bank's exit signal in the first three instances and the bank's voice in the fourth. Moreover, we observe that market and legal mechanisins exist that mitigate the most serious instances of conflict-instances of asset-grabbing that do not convey valuable information. These protective mechanisms discourage inefficient exit and voice, and thereby enhance the net benefits from the role of bank lenders in interactive corporate governance.

\section{A. Lender Exits Early for Reasons Unrelated to Managerial Slack}

A lender's exit is different in nature from that of a holder of traded debt or equity. The latter investor can exit without interacting with the firm, by selling its interests in an established market. The cost of premature exit is borne by the sellers of those securities. Typically, a bank cannot exit simply by dealing with a third party. ${ }^{69}$ Therefore, the lender and borrower negotiate the terms of the bank's exit at the time of contracting. They agree to the conditions upon which the lender is entitled to cut off financing, to demand repayment of the outstanding debt, and to enforce its debt against the assets of the borrower.

The lender's exit rights provide an important disciphne on managerial slack. They also constrain the ability of other stakeholders, particularly shareholders, to capture the loyalty of management to the detrinent of debtholders (borrower misbehavior). In its contract with the borrower, a lender could retain unconditional discretion to exercise any or all of its exit options. ${ }^{70}$ However, the lender may subsequently use its discretionary right of exit for strategic purposes unrelated to managerial slack or borrower misbehavior. One example of such lender opportunisin is where a bank terminates its contract with the borrower to escape a deal that has become unfavorable for exogenous reasons such as a rise in the risk-free rate of interest in the case of a fixed-rate loan. The lender's contractual rate of

69. There is a new and growing market for bank loans, even high-risk and high-yield loans. Dennis McCrary \& Jo Ousterhout, The Development and Future of the Loan Sales Market, J. APPLIED Corp. Fin., Fall 1989, at 74. However, loans are typically sold shortly after they are made and the borrowers are not in financial distress. See id. at 75 (describing reduced role of many banks as "holders" of loans, and increased role as originators). Banks are discouraged from selling loans midstream by an accounting rule issued by the Federal Accounting Standards Board ("FASB") in 1993, FASB Statement of Financial Accounting Standards No. 115. When a bank sells a loan before its maturity, the FASB rule forces the bank to value the entire portfolio of loans at current prices, rather than at their original cost. See Lee Berton, Banks Anticipate the Crunch of New Accounting Rule, WALL ST. J., Jan. 5, 1995, at B4.

70. For example, a lender may make a demand loan or may reserve the right to accelerate maturity whenever it deems itself to be insecure. However this right is limited to the degree that the Uniform Commercial Code imposes a good faith requirement on acceleration. See U.C.C. $\$ 1-208(1990)$. For the distinction between a commitment to advance funds and a line of credit under which the lender retains discretion to advance, see Midatlantic Nat'l Bank v. Commonwealth Gen., Ltd., 386 So. 2d 31, 33 (Fla. Dist. Ct. App. 1980) (noting that a line of credit does not impart to the bank legal responsibility to loan up to the limit of the line). 
return likely will be discounted ex ante by the expected cost to the borrower of the potential for lender opportunism or costly contractual terms may be chosen to reduce the incentive for opportunistic exit (for exanıle, a floating interest rate).

There are several niarket and legal constraints on lender opportunisn1. First, banks receive higher interest rates than other debt investors at least partly because other constituencies can rely on bank monitoring, exit, and voice to serve their collective interest. When a bank is a repeat player, this premiun1 would be compromised by observable opportunistic abuse of its acceleration rights. However, the effectiveness of the reputational sanction depends on the ability of the market to distinguish opportunistic bank exit froin exit that is justified by a loss of confidence in the management of the borrower. Second, while courts generally respect contract provisions giving lenders discretion to cut back or terminate financing at any time, ${ }^{71}$ they have at times fettered the lender's exit options by requiring that the lender act in good faith and give the borrower reasonable notice before exit. ${ }^{72}$ The notice and good faith requirements reduce the risk of lender opportunism. However, the courts are no better, and are probably worse, than the inarket in distinguishing between cases of opportunistic lender behavior and circuinstances where lenders are reacting to managerial slack or borrower inisbehavior. As a result, an evolving doctrine of lender liability would inpede the lender's ability to respond to misbehavior by exiting or threatening to exit, and thereby raise the cost of bank credit. ${ }^{73}$ Indeed, in light of the positive governance externalities of bank activities, such judicial intervention would have a broader adverse effect on the cost of capital generally.

71. See, e.g., Kham \& Nate's Shoes No. 2, Inc., v. First Bank of Whiting, 908 F.2d 1351, 1354, 1357-59 (7th Cir. 1990) (denying equitable subordination where bank exercised contractual right to terminate financing at any time on five days' notice); In re Clark Pipe \& Supply Co., Inc., 893 F.2d 693, 695, 700 (5th Cir. 1990) (concluding that lender did not act inequitably in exercising right under line of credit agreement to reduce advance ratio for inventory by $5 \%$ per month).

72. For instance, in the case of K.M.C. Co. v. Irving Trust Co., 757 F.2d 752 (6th Cir. 1985), the parties agreed to a $\$ 3.5$ million line of credit facility under which all advances by the lender were discretionary and outstanding loans were payable on demand. The Sixth Circuit held that the lender had an obligation to give notice before refusing to advance funds under the line of credit and a duty to act in good faith in demanding repayment of outstanding amounts. Id. at 759-60. But see Kham \& Nate's Shoes, 908 F.2d at 1358 (holding that bank need not give any more notice than its contract requires). The discretion of a lender to accelerate the maturity of the indebtedness at will or when it deems itself to be insecure is subject to a requirement that the lender must at the time of acceleration believe in good faith that the prospect of the borrower's repayment is impaired. U.C.C. $\$ 1-208$ (1990). Contra U.C.C. § 1-208 Official Comment (stating that $\S 1-208$ does not apply to demand instruments or obligations that by their very nature permit call at any time for any reason); National Westminster Bank, U.S.A. v. Ross, 130 B.R. 656, 680 (Bankr. S.D.N.Y. 1991), aff'd sub nom. Yaeger v. National Westminster, 962 F.2d 1 (2d Cir. (N.Y.) 1992); Spencer Companies, Inc., v. Chase Manhattan Bank, N.A., 81 B.R. -194, 199 (Bankr. D. Mass. 1987).

73. See Daniel R. Fischel, The Economics of Lender Liability, 99 YALE L.J. 131, 143-44 (1989) (noting that notice requirements, ostensibly designed to curb opportunistic behavior by lenders, may end up encouraging opportunistic behavior by borrowers). 
In order to reduce the scope of lender opportunism, the parties often condition the bank's right to accelerate the maturity of a loan on the occurrence of an event of default specified in the contract, rather than leaving the right to the lender's discretion. ${ }^{74}$ Default may be triggered by the borrower's failure to meet its payment obligations or by its violation of any other covenant in the debt contract. Current corporate scholarship explains covenants as a means of bonding the commitment of the firm to refrain from behavior that redistributes wealth from debtholders to shareholders or from investors as a group to managers. ${ }^{75}$ These covenants restrict actions such as shareholder distributions, issuance of senior or secured debt, and combinations with other corporations. If a loan agreement contains restrictive covenants and the lender diligently monitors compliance by the borrower, all investors benefit from the consequent deterrence of misbehavior.

While debt covenants are well understood as bonding mechanisms, they are much less appreciated for the role they play in triggering investor activism. They serve as trip wires for the lender's right to accelerate and enforce or to intervene in the borrower's decisions. The function is perhaps most apparent in covenants that impose financial ratio tests on borrowers and require periodic reporting. ${ }^{76}$ The covenants in bank loan agreements are usually designed to be tripped well before the borrower either misses a payment or becomes insolvent. Therefore, by being immediately notified of the borrower's financial difficulties, the lender has the opportunity to act well before the borrower becomes insolvent. If a lender exits, its action sends a signal that an event of default may have been triggered by either a payment default or a covenant violation. Consistent with the interactive nature of corporate governance, stakeholders who observe the signal are on notice that closer investigation of the firm's condition inay be in order. Thus, depending on the lender's reaction, covenants are valuable in either triggering its intervention or in enhancing its exit signal.

Nevertheless, covenants are imperfect predictors of when bank exit or intervention is optiinal: a trip wire may be triggered because of an exogenous shock to the firm ratler than inanagerial slack. When a lender detects a violation, it has the right to accelerate, but no legal obligation to do so. The bank has several options: to accelerate the maturity, to grant a period of grace, to waive the default, or to inodify the covenant to eliminate the default. Covenants reduce, but do not eliminate, the scope for lender oppor-

74. Many lending agreements combine specific events of default with a provision allowing the lender to accelerate when it deems itself insecure or its collateral to be in jeopardy. However, partly for reputational reasons and partly because of the risk of liability mentioned above, see supra note 72 and accompanying text, lenders much prefer to accelerate following the occurrence of a specified event of default.

75. See, e.g., Clifford W. Smith, Jr., \& Jerold B. Warner, On Financial Contracting: An Analysis of Bond Covenants, 7. J. Fin. EcoN. 117 (1979).

76. Indeed, banks should perceive a borrower's failure to meet reporting requirements as an early sign of trouble. 
tunism. The lender may still use its acceleration right on a false alarm to escape a bad deal (for example, when the market rate of interest has risen since the agreement) or to extract concessions from the debtor. ${ }^{77}$

\section{B. Lender Reacts Too Late}

Like any other stakeholder, a bank lender has the incentive to free-ride on the momitoring and reactions of others. As a result, a bank might not detect managerial slack until the problem is too severe to be corrected. However, the spoils from a deteriorating firm are divided among unsecured creditors on a first-come-first-served basis. Therefore, an unsecured creditor will likely shirk im its monitoring function only to the point that it can still detect the inipending failure of the firm before other creditors. It may use its information advantage to ensure that it is first in line, rather than to police the behavior of nianagenient. As a result, managerial slack is insuffciently deterred and intervention by other stakeholders is triggered too late. $^{78}$

Bankruptcy law, however, threatens to penalize this type of strategy. Even if a lender is first in line among its borrower's creditors, it may not be able to exit after the debtor has become insolvent. If an unsecured bank lender receives payment or enforces its claim within 90 days before bankruptcy and the debtor is insolvent at the tinie of the transfer, the transfer is a voidable preference and the bankruptcy trustee can recover the payment from the bank to the extent the bank was undersecured. ${ }^{79}$ The conventional explanation for preference law is that it deters asset-grabbing on the eve of bankruptcy. ${ }^{80}$ However, this theory does not explain why the debtor must be insolvent at the time of the payment to the creditor. The interactive theory supplies a more coniplete explanation. The voidable preference rule encourages timely monitoring and pre-insolvency action by threatening to reverse any attenipt to exit after the debtor has become insolvent. Although the rule tends to underdeter preferences by msolvent debtors, ${ }^{81}$ it provides

77. See infra Part II.C.

78. The demise of Olympia \& York may be partly explained in this manner. The first signal of financial trouble appeared in the market for the firm's commercial paper, rather than from its banks. Many observers felt that its main bank, the Canadian Imperial Bank of Commerce, had been caught asleep at the wheel. See, e.g., Jacquie McNish, How Banks Flubbed $O \& Y$, THE Globe \& MAIL (Toronto ed.), Dec. 4, 1992, at Al.

79. 11 U.S.C. $\$ 547(b)$ (1994). Section $547(b)(3)$ requires that the transfer must be made while the debtor is insolvent. Insolvency is defined by a balance sheet test in 1 I U.S.C. § I01(32) (I994): the sum of the firm's debts is greater than the fair value of its nonexempt property, other than property transferred, concealed or removed with intent to hinder, delay or defraud the firm's creditors. The debtor is presumed to have been insolvent in the 90 -day period prior to bankruptcy. 11 U.S.C. $\$ 547(f)$ (1994).

80. See, e.g., Thomas H. Jackson, Avoiding Powers in Bankruptcy, 36 StaN. L. Rev. 725, 756-61 (1984).

81. At the time of the transfer from the insolvent debtor, there is a chance that bankruptcy will not occur within 90 days. Moreovcr, interest on the amount transferred runs only from the time the bankruptcy trustee challenges the transfer. At most, therefore, the operation of the rule simply restores 
some incentive to a lender to observe early warning signs and to blow the whistle before the debtor becomes insolvent. ${ }^{82}$ This incentive is important because the signal from a bank is of little value after the onset of insolvency since other creditors are often already aware of the insolvency through their respective interactions with the debtor. If the bank does not signal before the firm becomes insolvent, it has in a sense failed its momitoring role and is compelled to participate in the loss-sharing in bankruptcy.

On the other hand, transfers to fully secured lenders within the 90-day period before bankruptcy are not voidable preferences and therefore the secured lender's incentive to act early is weaker. ${ }^{83}$ Moreover, the secured lender is assured of its priority position and does not participate in the race to the courthouse. However, a secured lender who fails to notice or act on early signs of distress may nevertheless be penalized. If bankruptcy is imitiated before the lender enforces its security, the lender is subject to the automatic stay on the exercise of enforcement rights, ${ }^{84}$ entitled to interest only to the extent it is oversecured, ${ }^{85}$ and may ultimately be compelled to compromise its claim in a reorganization plan. ${ }^{86}$ Indeed, in certain circumstances a secured creditor may be required to return repossessed collateral to the debtor. ${ }^{87}$ This authority may be explained in the interactive model as providing an incentive to a secured creditor to move early enough to ensure that it completes both repossession and sale before the initiation of bankruptcy. Arguably, the case law also recognizes that, in sonie cases, the mere repossession of collateral may not be as clear a signal to other stakeholders as its sale. ${ }^{88}$

In sum, bankruptcy law provides unsecured lenders and, to a lesser but still significant extent, secured lenders with incentives to monitor diligently and to act upon early evidence of deterioration. If the bank acts early enough and conspicuously enough, it leaves to the other investors the possi-

the status quo. John C. McCoid, II, Bankruptcy, Preferences, and Efficiency: An Expression of Doubt, 67 VA. L. REv. 249, 264-65 (I98I).

82. Alternatively, if the bank fails to move before the debtor becomes insolvent, the bank may protect its payment by propping up the debtor for 90 days and concealing the firm's financial distress. However, the bank runs the risk that other creditors will make independent observations of the debtor's condition and petition the firm into bankruptcy before the end of the 90-day period. Therefore, the optimal ex ante strategy may be to detect financial distress and react before the debtor becomes insolvent.

83. See II U.S.C. $\$ 547(b)(5)$ (I994) (transfer is preferential only if it enables the creditor to receive more than it would receive in liquidation under Chapter 7 ).

84. II U.S.C. $\$ 362(a)(5)$ (I994).

85. 11 U.S.C. $\$ 506($ b) (I994).

86. See 11 U.S.C. $\$ 1129$ (b) (1994). The secured creditor also faces a significant degree of uncertainty about its payoff in bankruptcy.

87. See United States v. Whiting Pools, Inc., 462 U.S. 198 (1983).

88. The secured creditor is obliged to give notice, to the debtor and to other creditors with security interests in the collateral, of its intention to resell the collateral. U.C.C. $\$$ 9-504(3) (1990). The usual explanation for this notice provision is that it improves the ability of other creditors to monitor the sale of the collateral. See id. at cmt. 5 . 
bility of resolving the firm's troubles before the onset of bankruptcy. Indeed, if sent early enough, the bank's signal may be received by more skilled governance players who can instigate the desired change more efficiently than the bank. However, if the signal is sent too late to prevent bankruptcy, the bank will be forced to share in the loss as a consequence of the failure to detect managerial slack early enough for the slack to be corrected.

\section{Lender Uses Its Leverage to Improve the Terms of Its Debt}

A lender may choose to defer exit and instead use its threat of exit to induce management to renegotiate the terms of the debt. This strategy is successful only to the extent that the lender's threat is credible, which in turn depends on the cost of exit to the lender. ${ }^{89}$ Moreover, the borrower enjoys its own exit options, which limit the potential gains from lender opportunism: it can find a new lender or it may file for bankruptcy protcction. ${ }^{90}$ Therefore, the value that is appropriable by the first lender is capped by the cost to the borrower of obtaining replacement financing ${ }^{91}$ and the lender will not press the debtor too hard if the lender stands to lose value im bankruptcy.

Since monetary conccssions either involve cash payments or an increase in fixed obligations, they increase the risk of the borrower's insolvency. Therefore, lenders often request nonmonetary adjustments such as convertibility options, warrants, or more restrictive covenants as conditions for waiving defaults or granting periods of grace. Frequently, they seek to improve their position by taking new or additional security interests or guarantees. However, to bypass the preference rule in bankruptcy, both the issuance and perfection of new security must occur either outside the 90-day period before bankruptcy or while the debtor is still solvent. ${ }^{92}$ Furthermore, the modification of a debt contract is often a material change in the borrower's condition that must be disclosed by public issuers under securities laws..$^{93}$ Additionally, the perfection of a security interest issued by the debtor is a public act which requires either possession of the collat-

89. See supra text accompanying notes $56-59$.

90. The lender may have a good faith anty to give the borrower reasonable time to find replacement financing. See discussion supra note 72 . The protection of the automatic stay and the availability of debtor-in-possession financing provide the incentive for cash-strapped borrowers to file for bankruptcy. See George G. Triantis, A Theory of the Regulation of Debtor-in-Possession Financing, 46 VAND. L. REV. 901 (1993).

91. Fischel, supra note 73, at 138 ("The size of any concessions must be smaller than the costs to the debtor of negotiating with a new lcnder.").

92. Within the 90-day period, an insolvent debtor cannot grant a security interest to its lender unless the lender contemporaneously extends new crcdit. See 11 U.S.C. $\S 547(b)(c)(1)$ (1994).

93. A corporation is rcquired under securities laws to disclose significant modifications in its agreements with lenders, including the issuance of new security interests. See supra note 53. 
eral or filing with a state agency. ${ }^{94}$ Other stakeholders may be prompted by such a signal to exit or intervene to control managerial slack. Indeed, the prospect of a concession may serve as an inducement to the bank to monitor and, if contained, it may be a relatively modest price to pay for a signal that triggers the remedial interactive governance process. ${ }^{95}$

In the discussion thus far, the lender receives a concession from the borrower in response to the lender's simple threat of exit. However, a lender that tries to improve its position against other creditors by intervening more substantially in the borrower's decisions and exercising control over firm decision-making - rather than merely exploiting its exit threatis more likely to lose the advantage in bankruptcy. The voidable preference period is extended to one year prior to bankruptcy if the transferee of the payment or security interest is deemed to be a person with sufficient control of the debtor (an "insider"). ${ }^{96}$ Despite the longer preference period, it remains a requirement that the debtor be insolvent at the time of the transfer. The granting of a security interest to a controlling lender (an insider) may also be a fraudulent conveyance if the debtor had actual intent to himder, delay, or defraud any other creditor. ${ }^{97}$

The bankruptcy doctrine of equitable subordination further acts to deter opportunistic lender behavior. This doctrine authorizes the court to subordimate a lender's claim if the lender obtains an advantage at the expense of other creditors as a result of its control over the borrower's man-

94. U.C.C. $\$ 9-302,9-304,9-305$. However, a lender whose debt is secured by a floating lien over inventory or receivables may induce the firm to increase its purchases of inventory or create receivables by lowering prices and increasing sales. The voidable preference rule reverses any benefit resulting from increases in the value of the lender's collateral while the debtor was insolvent in the 90day period prior to bankruptcy. See 11 U.S.C. $\$ 547(c)(5)$ (1994) (the two-point improvement test). However, the build-up of inventory or receivables before insolvency is beyond the reach of the preference provision and significantly more difficult to detect than the acquisition and perfection of new security interests, which require public filings. Therefore, a bank that induces the build-up of inventory or receivables enhances its position relative to other creditors in a manner that is unlikely to serve as a signal that galvanizes intervention by other stakeholders.

95. In fact, the adjustments agreed to by the borrower may yield other positive externalities. For example, the granting to a lender of a security interest, more restrictive covenants, or a convertibility option may benefit other fixed claimants by deterring managerial misbehavior and controlling the tendency of the borrower to increase its risk-taking.

96. 11 U.S.C. $\$ 547(b)(4)(B)$ (1994).

97. Most states have adopted either the Uniform Fraudulent Conveyances Act (U.F.C.A.) or the Uniform Fraudulent Transfer Act (U.F.T.A.). A bankruptcy trustee may use these provisions by virtue of its power under 11 U.S.C. $\$ 544$ (1994). The Bankruptcy Code has its own provision in $\S 548(a)$, which reviews transfers made on or within one year prior to bankruptcy. Under all provisions, a transfer is voidable if the debtor had actual intent to hinder, delay, or defraud any other creditor. U.F.C.A. $\S 7$ (1918); U.F.T.A. § 4(a)(1) (1984); 11 U.S.C. § 548(a)(1) (1994). Unlike the other Acts, the U.F.T.A. provides factors to assist courts in determining actual intent. One such factor is whether the transferee is an insider. U.F.T.A. § 4(b)(1) (1984). Another factor is whether the debtor was insolvent or became insolvent shortly after the transfer. U.F.T.A. $\S 4(b)(9)$ (1984). However, insolvency of the transferor is presumably not a necessary condition under any of the Acts. 
agement. ${ }^{98}$ The clearest case of control (de jure control) is a lender who holds a majority block of voting shares of its borrower, either directly or through a pledge of the shares. ${ }^{99}$ However, the equitable subordination doctrine also recognizes the leverage over day-to-day operations that stems from instruments other than equity voting rights (de facto control). ${ }^{100}$ To trigger equitable subordination, the lender must essentially displace the decision-making capacity of the borrower's management. ${ }^{101}$ Bankruptcy courts scrutinize the behavior of a lender who exercises control over its borrower's cash flow: for instance, by holding an assignment of accounts receivable or signing authority on the debtor's current account. ${ }^{102} \mathrm{~A}$ lender with the requisite degree of control over its borrower's business operations also runs the risk of being held accountable for its actions under a fiduciary standard. ${ }^{103}$ Therefore, if the lender uses its control over the borrower to obtain an advantage at the expense of other creditors, it may find its claims subordimated to unsecured claims. For instance, if a controlling lender

98. See 11 U.S.C. $\$ 510$ (c) (1994). Most courts that apply the doctrine of equitable subordination require the lender in control (an insider) to have engaged in inequitable conduct that resulted in injury to other creditors or conferred an unfair advantage on the lender. See, e.g., In re Mobile Steel Co., 563 F.2d 692, 699-700 (5th Cir. 1977). If the lender does not have sufficient control to be vicwed as an insider, the courts have imposed a stricter test of egregious conduct such as fraud or misrepresentation. See, e.g., In re Osborne, 42 B.R. 988, 996 (Bankr. W.D. Wis. 1984) (noting that the main differences between subordinating the claims of insiders and non-insiders "lie in the severity of the misconduct ... and the degree to which the court will scrutinize" the actions (quoting In re Tcltronics Serv., Inc., 29 B.R. 139, 169 (Bankr. E.D.N.Y. 1983))).

99. See, e.g., In re American Lumber, 5 B.R. 470, 478 (D. Minn. 1980) (subordinating claim of lender with right to vote pledged shares in borrower); In re Process-Manz Press, Ine., 236 F. Supp. 333, 337 (N.D. Ill. 1964) (subordinating claim of lender with voting rights in over $90 \%$ of borrower's common stock), rev'd on jurisdictional grounds, 369 F.2d 513 (7th Cir. 1966).

100. In the absence of de jure control, the courts look for de facto control over the day-to-day operations of the debtor. See generally In re Auto Specialties Mfg. Co., Inc., 153 B.R. 457, 477-94 (Bankr. W.D. Mich. 1993) (discussing the mechanisms of de facto and de jure control, and their relevance to the doctrine of equitable subordination).

101. In this regard, the Fifth Circuit drew the following distinction:

Through its loan agreement, every lender effectively exercises "control" over its borrower to some degreee. A lender ... will usually possess "control" in the sense that it can foreclose or drastically reduee the debtor's financing. The purpose of equitable subordination is to distinguish between the unilateral remedies that a creditor may properly enforce pursuant to its agreements with the debtor and other inequitable conduct such as fraud, misrepresentation, or the exercise of such total control over the debtor as to have essentially replaced its decision-making capacity with that of the lender.

In re Clark Pipe \& Supply Co., Inc., 893 F.2d 693, 701 (5th Cir. 1990) (emphasis added).

102. See, e.g., American Lumber, 5 B.R. at 478 (subordinating claim of lender that foreclosed on its security interest in the debtor's receivables and contract rights and refused to honor the debtor's payroll checks); Process-Manz, 236 F. Supp. at 339 (subordinating claim of lender that held assignment of receivables, collected the proceeds, and supplied the funds for payroll and other expenses).

103. See, e.g., In re Teitronics Servs., Inc., 29 B.R. 139, 170-71 (Bankr. E.D.N.Y. 1983). A fiduciary relationship is sometimes the basis for assiguing liability to a lender and at other times is an intermediate finding toward equitably subordinating the debt claim of the lender. See, e.g., Auto Specialties, 153 B.R. at 478-79 ("The claim of a non-fiduciary creditor generally will not be equitably subordinated unless egregious conduct on behalf of the creditor can be proven with particularity."); In re Ludwig Honold Mfg. Co., Inc., 46 B.R. 125, 129 (Bankr. E.D. Pa. 1985) (under either the fiduciary or nonfiduciary standard, the creditor must engage in inequitable conduct to warrant subordination). 
receives a new security interest ${ }^{104}$ or benefits from an increase in the value of an existing security interest at the expense of unsecured creditors, ${ }^{105} \mathrm{a}$ court in a subsequent bankruptcy proceeding may subordinate the lender's claim to those of other creditors.

In sum, a lcnder is relatively free to improve its position by exiting a financially distressed firm, provided it does so before the firm becomes insolvent. The gain from early exit serves as an incentive for early action, and implicit compensation for the signal communicated by the exit to other stakeholders of the firm. In contrast, a lender who chooses instead to intervene in the decision-making process of its borrower seems to lose a signifcant part of this immunity and must be careful if it subsequently decides to exit. Therefore, a lender is forced to evaluate the likely efficacy of its voice options at the time it detects managerial slack. If it lacks the necessary expertise, then, from an interactive governance perspective, it should exit rather than intervene in order to signal and prompt active intervention by more effective stakeholders.

\section{Bias in Lender Voice}

The legal ineclianisms described in the previous section act to constrain the most flagrant abuses of the leverage enjoyed by the bank over its borrower's management. If the bank simply uses its exit threat to obtain a concession during the 90-day period before bankruptcy and while the borrower is insolvent, the voidable preference provision may reverse the advantage. If the bank intervenes extensively in the decision-making process of the borrower, it may be held to a higher standard of conduct under the insider provisions of the voidable preference and fraudulent conveyance provisions, as well as under the doctrine of equitable subordination. However, judicial scrutiny under these provisions appears to be limited to actions induced by the controlling lender (or insider) that unambiguously improve the value of the lender's exit option at the expense of other creditors: for example, the granting of new security or the acquisition of additional property covered by the lender's existing security interest. These are clear instances of conflict between the main lender and the other creditors.

In addition to using its exit threat to improve the terms of its loan, the bank may instead exercise its voice to replace managers or to induce

104. See, e.g., In re Beverages Int'l Ltd., 50 B.R. 273, 284 (Bankr. D. Mass. I985) (subordinating claim of creditor who delayed in obtaining and recording a blanket security interest to encourage third parties to extend credit to the debtor); American Lumber, 5 B.R. at 478 (subordinating claim of controlling lender who received new security interests in inventory and equipment from its distressed borrower).

105. See, e.g., American Lumber, 5 B.R. at 478 (finding that, through its control over the disbursements of the debtor, a lender permitted only those payments that were likely to enhance or preserve the value of its collateral). 
changes in the investment or financing strategy of existing management. ${ }^{106}$ At least at first glance, such actions would appear to address the problems of managerial slack. However, the bank's intervention is a bundled good which raises imter-investor conflicts and concerns about bias with respect to investment, financing, and personnel decisions. When a firm is at or near imsolvency, the tensions among the interests of mvestor groups intensify, particularly with respect to risk taking. As a result, to the extent that bank lenders can influence the firm's business strategy, shareholders worry that the firm's decisions may be too conservative in seeking to contain further losses rather than pursuing profitable ventures. ${ }^{107}$

This argument, however, may be overstated. Even at the best of timcs, it is difficult to establish a governance process that aligns managerial incentives with the collective interests of all stakeholders. No single investor or class of investors can represent the collective interest of all stakeholders of an insolvent firm. The neoclassical model of the firm proposes that, given an imperfect world, the optimal solution is to vest decision making authority with the residual claimants, who gain or lose at the margin from the actions of the firm. Accordingly, several commentators argue that decisionmaking authority should pass from shareholders to unsecured creditors when a firm becomes msolvent because unsecured creditors become the de facto residual claimants at the inargin. ${ }^{108}$ If the bank is unsecured, it may be an excellent representative of this class, providing it does not use its authority to improve its position relative to the other members of its class. As we have seen, several mechanisms exist to control this type of opportunistic behavior by banks: fraudulent conveyances, voidable preferences, and equitable subordination.

In inany cases, however, the bank is secured and is therefore not a residual claiinant. Even so, a bank has an interest in the recovery of the firm as a going concern because of the prospect of continued or even

106. With respect to the lender's right to terminate existing management, see Buckley, supra note 23, at 267-89. Empirical studies reveal a significant degree of bank involvement in termination decisions in financially distressed firms. Stuart C. Gilson, Management Turnover and Financial Distress, 25 J. FIN. EcoN. 241, 248-52 (1989) (finding bank pressure to be third most important factor in termination decisions); Lynn M. LoPucki \& William C. Whitford, Corporate Governance in the Bankruptcy Reorganization of Large, Publicly Held Companies, 141 U. PA. L. Rev. 669, 737 (1993) (finding evidence of creditor pressure in $45 \%$ of termination decisions in sample). Stuart Gilson also found that the representation of banks on the borrower's board increased during period of financial distress. Gilson, supra note 55, at 365 .

107. See, e.g., Joseph E. Stiglitz, Credit Markets and the Control of Capital, 17 J. MONEY, Credr, \& BANkING 133, 146 (1985) ("Lenders are only concerned with the bottom part of the tail of the distribution of returns.").

108. See, e.g., Thomas H. Jackson, The Logic and Limits of Bankruptcy Law 167-69 (1986) (identifying unsecured creditors as residual claimants during insolvency); $c f$. Douglas G. Baird, Fraudulent Conveyances, Ageney Costs, and Leveraged Buyouts, 20 J. Legal Stud. 1, 10-11 (1991) (same). 
increasing returns from future dealings with the borrower. ${ }^{109}$ It stands to reap increased business from a successful firm because it has an information advantage over outside lenders in bidding for financing opportunities in the recuperated borrower. Moreover, if the bank lias a perfected, broad security interest, it enjoys a situational inonopoly over the firm's future borrowing needs. ${ }^{110}$ Therefore, banks often do participate in the upside prospects of their borrowers and this participation may dampen some of the divergence in perspective on investment strategy. Moreover, the relative effectiveness of the bank's voice in correcting inanagerial slack may outweigh the cost to the collective interest of any residual bias. Shareholders of a firm in financial distress have a strong risk-taking bias and unsecured creditors inay lack expertise or be too diffuse to effectively temper that bias. The secured bank-lender's intervention nay be no worse than that of any other constituency. Indeed, the problein may be instead that the bank is inore tempted by the exit option than the opportunity to intervene.

In this light, ex post judicial review of business decisions involves difficult and unpredictable determinations that are likely to deter desirable intervention by banks to relnedy managerial slack. As evidenced by the business judgment rule that governs judicial review of management decisions, the courts are well aware of the difficulty of second-guessing corporate decisions. Accordingly, courts have generally not held lenders liable for their influence on their borrowers' business decisions. The voice of a lender ranges from advice and exhortation to exclusive control over the firm's decisions. It may be general or specific in content and it may range froin permissive to coinpelling in force. ${ }^{111}$ A lender who intervenes with mimimal force by suggesting courses of action to the borrower's manageinent is unlikely to be found liable for the consequences of any decisions made in response to its recommendation, even if the recommendation is coupled with a threat of exit. ${ }^{112}$ A lender who uses its threat of exit to

109. See Scott, supra note 35, at 916-19. indeed, other fixed claimants, such as suppliers and trade creditors, enjoy similar upside prospects.

110. Thomas H. Jackson \& Anthony T. Kronman, Secured Financing and Priorities Among Creditors, 88 YALE L.J. 1143, 1167-74 (1979).

111. As the bank's voice becomes more forceful, its legal responsibility for the actions of the borrower increases. In the extreme case of absolute control, the lender may be deemed to be in a fiduciary relationship with the borrower. Under the theories of agency, instrumentality, or alter ego, the lender may then be held liable for debts incurred by the borrower during this period. See generally Note, Lender Liability: A Survey of Common-Law Theories, 42 VAND. L. REv. 855, 862-67 (1989). See also Krivo Indus. Supply Co. v. National Distillers \& Chem. Corp., 483 F.2d 1098, 1102-07 (5th Cir. 1973) (describing the instrumentality doctrine in depth, before concluding that its applicability had not been established as a matter of law in the case at bar), modified and reh' $g$ denied, 490 F.2d 916 (5th Cir. 1974). If the court finds a principal-agent relationship, the lender may be liable for its borrower's debts even if it has acted honestly and with due care in the exercise of its control. See Restatement (Second) of Agency, $\S 140$ (1958). See generally J. Dennis Hynes, Lender Liability: The Dilemma of the Controlling Creditor, 58 TENN. L. REV. 635 (1991).

112. See, e.g., In re Prima Co., 98 F.2d 952, 965 (7th Cir. 1938) (holding that the lender's threat was exercise of its legal right, and that borrower's acquiescence to demands did not demonstrate 
restrict certain actions or influence discrete decisions of the borrower will probably not be held responsible to other investors. ${ }^{113}$ There are a few exceptions in the case law that increase the risk of intervention, ${ }^{114}$ but findings of liability remain relatively rare. Indeed, potential gatekeeper liability under securities or environmental laws nnay present more of a threat than traditional lender liability doctrine. ${ }^{115}$ The risk of lender liability is probably imsufficient to deter intervention by banks who have otherwise both the incentive and expertise to take steps to correct managerial slack.

In the interactive model, the doctrine of lender liability may serve to screen stakeholders to ensure that the actor exercising voice has the best incentive and expertise to correct managerial slack. If a bank has either inappropriate incentives or inadequate expertise, the risk of lender liability generally discourages it froin ineddling in the decision-making of the firm, particularly for the purpose of promoting selfish interests that conflict with those of investors as a group. In such a case, the theory of interactive governance assigns to the bank simply the task of signalling its detection of slack by exiting. The task of instigating change in the firm is thereby left to other, better-qualified and better-placed stakeholders. Moreover, where there are severe conflicts of interest among stakeholders in a financially distressed firm, the bankruptcy process offers an alternative-albeit costly-mechanism in which all constituencies may be represented and heard and the management of the firm continues under judicial oversight. Indeed, bankruptcy law should be seen as providing the ineans to correct managerial slack when the other mechanisms described in this Article have failed. ${ }^{116}$

sufficient lender control), cert. denied, 305 U. S. 658 (1939); In re Technology for Energy Corp., 56 B.R. 307, 313-17 (Bankr. E.D. Tenn. 1985) (refusing to find control where lender made suggestions while threatening to exit).

113. See, e.g., In re Teltronics Ser., 29 B.R. 139, 172-73 (Bankr. E.D.N.Y. 1983) ("There is nothing inherently wrong with a creditor carefully monitoring his debtor's financial situation ... . or with suggesting what course of action the debtor ought to follow."); In re W.T. Grant Co., 4 B.R. 53, 76-77 (Bankr. S.D.N.Y. 1980). However, a lender who has absolute veto over all business decisions may be found to be in control and subjected to a higher standard of conduct. See supra notes 96-105 and accompanying text and supra note 111 .

114. A notorious example is State Nat'l Bank of El Paso v. Farah Mfg. Co., 678 S.W.2d 661, 686 (Tex. Ct. App. 1984) (holding lender liable where it threatened to call loan if a past CEO were reinstated), error granted, set aside, dismissed as settled. For a critique, see Fischel, supra note 73, at 144-46. For another example of a claim of wrongful interference with contractual relations, see Kelly v. Central Hanover Bank \& Trust Co., 85 F.2d 61, 62 (2d Cir. 1936) (controlling bank induced issuance of secured debt in violation of negative pledge clause in bond indenture).

115. See, e.g., Securities Act of 1933 \$ 15, 15 U.S.C. $\$ 770$ (1994) (liability of controlling persons); Securities Exehange Act of 1934, § 20, 15 U.S.C. $\$ 78 \mathrm{t}$ (1994) (same); Comprehensive Environmental Response Compensation and Liability Act of 1980 ("CERCLA"), 42 U.S.C. $\S \S 9601$ 9675 (1988); 40 C.F.R. $\$ 300.1100$ (c)(2) (April 1992) (cleanup liability of secured commercial realestate lender who participates in management of debtor).

116. There may be an interesting link in this respect between the amount of debt issued by a firm and the objeetive of correcting managerial slack. In particular, the amount of a firm's liabilities might be set so that the occurrence of insolvency-the moment when the firm's value falls below the set amount of liabilities-will indicate to stakeholders the likelihood of persistent managerial slack. If the 
In sum, it is well known that covenants in bank financing agreements, when properly monitored for compliance, deter managerial slack and borrower misbehavior. In addition, the monitoring bank detects evidence of slack or misbehavior when it does occur. If the bank exits or takes new security in the assets of the borrower, it provides a signal to the other stakeholders that prompts intervention. Bank imtervention seems desirable in many cases because of the bank's significant stake in the borrower and its acquired information and expertise. To the extent that bank monitoring corrects nianagerial slack or borrower misbehavior, it benefits all investors. However, there are countervailing negative externalities steinming from the bank's ability to exercise its influence to work out a better (lower risk) deal for itself, rather than correct the problems with the borrower. The various legal mechanisms described above target flagrant instances of opportunistic use of bank voice and encourage the intervention of other, better-placed stakeholders. In the absence of such constituencies, the bankruptcy process offers a collective process of adjustment and reorganization under judicial oversight.

\section{II}

\section{The Mechanisms of Interactive Governance}

The decision to exit has two components: when to exit and whether to exit completely or merely reduce the size of the stake in the firm. Voice is a somewhat more complex reaction than exit. It can be measured along three dimensions: (i) tinie, (ii) specificity, and (iii) force. First, the temporal dimension is determined by the duration and frequency of voice. Some stakeholders opt for relatively brief, single-shot expressions of voice by, for instance, simply alerting management to certain problems that have become nianifest in the corporation. Conversely, other stakeholders make a more sustained commitment to voice, providing constant feedbaek and direction to management by, for instance, taking a seat on the board of directors. Second, voice may be a general exhortation (for example, to do better) or precise recommendations tailored to address specific problems (for example, dismiss certaim managers, terminate specific product lines, adopt certain projects). Third, voice may be accompanied by varying degrees of compulsion depending on the legal or economic sanctions that expressly or

slack cannot be corrected through the mechanisms discussed in this Article, then bankruptcy (reorganization or liquidation procedures) provides a (final) process for correcting the slack. Thus, unlike the conventional view of bankruptcy as a process for resolving financial distress while preserving going concem value, banktruptcy responds to the signal of financial distress to redress slack and thereby enhance the firm's value. George G. Triantis, The Interplay of Liquidation and Reorganization in Bankruptcy: The role of screens, gatekeepers and guillotines, 16 lNT'L REV. L. \& Econ. (forthcoming 1996). For a discussion of corporate governance in bankruptcy reorganizatious, see Lynn M. LoPucki \& George G. Triantis, A Systems Approach to Comparing U.S. and Canadian Reorganization of Financially Distressed Companies, 35 HARv. 1NT'L L.J. 267, 302-15 (1994); LoPucki \& Whitford, supra note 106. 
impliedly back the intervention. Thus, timing (composed of frequency and duration), specificity, and force define the decision space for voice, and the boundaries for any given stakeholder are determined by factors such as the stakeholder's strict legal rights, level of economic investment, organizational status, and exit threat. ${ }^{117}$

Once the annbit of a stakeholder's voice options is defined, the stakeholder uses a self-interested cost-benefit analysis to choose between exit and voice, and among voice options. ${ }^{118}$ Exit is usually the option that carries the most certainty; the value of voice, however, depends on the responsiveness of inanagers and their ability to effect change. This responsiveness, in turn, is a function of the quality of the information held by the actor, the boundaries of its voice options, and its expertise in choosing the most cost-effective configuration of voice. The vindication of stakeholder objectives is not always achieved most effectively by implementing voice decisions characterized by the maximum frequency, specificity, and force available to them. In particular, the effectiveness of voice in revcrsing deterioration depends as much on subtle manipulation as brute force. Moreover, the relationship between managerial performance and external pressure or force probably yields an interior optimal solution that involves less than maximum force. ${ }^{19}$

When exit is certain and cheap, a stakeholder is likely to prefer exit over voice. For example, a retail shareholder would usually sell her shares rather than attempt to correct slack by speaking or voting at annual meet-

117. For instance, the scope of voice discretion available to a low-level employee to control managerial slack is highly constrained because of hor limited legal rights, low organizational status, and the fact that she can be replaced at low cost if she resigns. The decision space for voice available to a shareholder may be broader because of her legal rights in directorial elections and the sharcholder proposal and approval process. On the basis of these rights, economic theory views shareholders as the principals of the corporation. However, a range of legal constraints (for example, bylaw-making power residing with directors, limited use of shareholder proposals, and restrictions on the ability of shareholders to call general meetings) impedes their ability to infiuence the management of the large, public corporation. As a result, shareholder voice is often surprisingly shallow in terms of the frequency, force, and precision of instructions it can provide to management. For a thoughtful analysis of this legal model, see generally Jeffrey N. Gordon, Shareholder Initiative: A Social Choice and Game Theoretic Approach to Corporate Law, 60 U. CIN. L. REv. 347 (1991).

118. Of course, the stakeholder may be able to choose a combination of exit and voice. For example, a shareholder may sell part of its interest and use the remainder as a leverage for voice. Shareholders are often viewed as enjoying a broader menu of voice options than cmployees and creditors who hold rule-oriented claims. Williamson, supra note 31, at 581-82. But see supra notes 5659 and accompanying text.

119. The genesis of this argument may be what is known as the Yerkes-Dodson law, which is supported by a variety of experimental results involving animals and humans. Robert M. Yerkes \& John D. Dodson, The Relation of Strength of Stimulus to Rapidity of Habit-Formation, $18 \mathrm{~J}$. Comp. Neurology \& Psychol. 459, 470-71 (1908); John Atkinson \& David BirCh, Introduction to Motrvation I48-49 (1978); see also George G. Triantis, Is Failure a Good Thing?: A Discussion of the Motivational Properties of Debt, Canadian L. \& Econ. Conf. Papers \& Proc., Sept. 1993 (arguing that while debt may provide specific goals that increase motivation, it may impair performance if the goals are set too high). 
ings. ${ }^{120}$ Indeed, this is precisely her role as contemplated by the interactive theory. In contrast, a stakeholder who has nade a substantial investment in or specific to the corporation usually faces a more complex decision because its exit is more difficult and it has broader voice options than the retail shareholder. Thus, a large shareholder who tries to sell its financial interest reveals information to the market and thereby impairs the terms on which it can exit. ${ }^{121}$ Conversely, by virtue of its stake in the firm, it can exert pressure on management, correct the slack in the firm, and increase the value of its investment. ${ }^{122}$ This combination of factors helps to explain the emerging role of active imstitutional investors who own large stakes in publicly held companies.

The exit or intervention of a stakeholder is prompted by information indicating an undesirable state of affairs. This information may be generated by the stakeholder's direct monitoring of the corporation or by a signal received from other stakeholders. To describe in general terms the monitoring effort, however, we begin with a solitary stakeholder who neither observes nor is affected by the actions of other constituencies. The level of monitoring effort undertaken by the solitary stakeholder depends on the nature of its access to valuable information. Some information is acquired casually in the course of the stakeholder's interaction with the firm. However, for the most part, information generation is the result of an explicit investment in the acquisition, processing, and interpretation of information. The cost of this activity is a function of variables such as expertise, technology, economies of scale, and, for stakeholders with multiple links to the firm, economies of scope. The benefits from nonitoring are inore difficult to evaluate because they are based on the probability of materialization of undesirable states and they are contingent on the choice of reaction options at that time. Yet, the availability and value of either exit or voice options depends in turn on the content of the information held by the stakeholder as a result of its monitoring. The extent to which the information is shared by others is also an important variable. For instance, exit based on stale or widely known information typically results in less net gaim than exit based on fresh information, but the effect of widely disseminated information on voice is nrore equivocal. In some cases, there may be clear first-mover advantages which limit the capacity of later actors to exercise

120. See Hirschman, supra note 2, at 46.

121. John C. Coffee, Jr., Liquidity Versus Control: The Institutional Investor as Corporate Monitor, 91 Colum. L. REv. 1277, 1329 (1991) (noting that exit by a block shareholder will lead to a "collapse" in the market price). Exit is also problematic for employees who have firm-specifie skills and face the additional hurdle of signaling their quality to other employers after they exit. See Ronald Daniels, Stakeholders and Takeovers: Can Contractarianism Be Compassionate?, 43 U. Toronro L.J. 315, 318-21 (1993) (discussing problems facing displaced employees after takeover).

122. The large shareholder with private information should be aware that the exercise of some types of voice must be disclosed to the market (for example, as required by securities regulation) and this may make future exit no easier than the current sale of the shareholder's significant stake. 
influential voice. ${ }^{123}$ In other cases, management may be more responsive to a broad-based coalition of stakeholders that can only be galvanized through a wide distribution of information. In any event, given the close interrelation between monitoring effort and reaction options, a stakeholder must subject its monitoring decisions to continuous cost-effective reassessment as the stakeholder receives new information respecting the efficacy of both monitoring and action over time. ${ }^{124}$

Whereas delegation of monitoring and reaction responsibility is alien (by definition) to the model of solitary stakeholder monitoring, it is germane to more realistic theories of interdependent stakeholder governance. The interdependent governance theory contemplates value-maximizing delegations of governance responsibility among stakeholders that take advantage of specialization in momitoring and reaction by assigning monitoring functions to the lowest-cost actors. The agent stakeholder "walks the beat" for the principal stakeholder, ${ }^{125}$ interveming where necessary to protect the interests of both parties. Delegations may be both within and between classes of stakeholders. Typically, interdependent theories of governance focus on delegations of authority within stakeholder classes: retail shareholders who rely on institutional shareholders, ${ }^{126}$ and secured creditors who rely on unsecured creditors. ${ }^{127}$ Delegations across distinct stakeholder groups are, however, seldom observed in the literature. ${ }^{128}$ In large part, lack of attention to these arrangements is a legacy of the power of financial agency theory and its central premise that distinct stakeholder classes have interests that conflict with one another. Yet, it is important not to overstate the importance of imterstakeholder conflicts. ${ }^{129}$ Even as between stakeholder classes, conflicting goals need not thwart efficient delegations of authority arising from a common concern with correcting managerial slack.

123. While all stakeholders share a common concern with controlling slack, stakeholder preferences may vary in tbe precise manner in which an idcntified instance of managerial misbehavior should be corrected. Shareholders and creditors both disdain managerial slack, but have different ways of resolving the misbehavior corresponding to their underlying utility functions. By moving first, a nimble stakeholder may be able to impose its preferences on the firm and preempt furthcr action by subsequent actors. Compared to a situation in which the slack goes completely uncorrected, the sccond mover's welfare is improved, though not as much as if he were the first mover.

124. For a description of the role of iterative information acquisition and processing in decision making, see George G. Triantis, Contractual Allocations of Unknown Risks: A Critique of the Doctrine of Commercial Impracticability, 42 U. TORONTO L.J. 450, 457-63 (1992).

125. This term is from Scott, supra note 35 , at 931.

126. See sources cited supra note 14.

127. See, e.g., Jackson \& Kronman, supra note 110, at 1152-58; cf. Levmore, supra note 21, at 55 59 (arguing that unsecured ereditors rely on secured creditors to monitor collateral scrving as focal points).

128. For notable exceptions, see sourees cited supra note 21.

129. As Coffee has shown, stakeholder coalitions within the corporation can emerge around various issues and at various times, only to dissolve later when conditions changc. Coffee, supra note 121; see also Daniels, supra note 121. 
As measured against the goal of controlling managerial slack, it is clear that a wide range of stakeholders have information and expertise that arise naturally from their relations with the firm and that can contribute to effective firm governance. For example, employees have access to information regarding internal production processes. Customers watch for changes in the quality of the goods or services produced by the firm. Suppliers observe the quality and quantity of the firm's inputs, as well as changes in the firm's accounts payable. Shareholders may obtain information through their representation on the board of directors. A bank lender may inonitor the firm's cash flows if the firm inaintains its current account with the bank. Hence, the task for institutional design is to ensure that the distinctive information available to each stakeholder group is impounded into the governance process. In this respect, the goals of corporate governance differ little from those of the efficient market-in F.A. Hayek's terms, to capitalize on "the knowledge of the particular circumstances of time and place." 130

Although the interdependent theory is sensitive to the potential for stakeholders to delegate governance authority across stakeholder classes, it fails to capture the rich texture of institutional arrangements that support multi-stakeholder governance. Specifically, the theory posits sweeping delegations of both monitoring and reaction responsibility that, at least as far as control of managerial slack is concerned, are not congenial to shared governance responsibility. The delegation of power from stakeholder to agent is crisp, encompassing, and static. Once the authority is delegated to an agent by a principal stakeholder, the principal's role as a governance actor virtually ceases. Henceforth, instead of monitoring the firm and devising appropriate reaction strategies, the principal stakeholder worries solely about the performance of its delegate.

In contrast to the interdependent theory, the interactive corporate governance theory sees stakeholder relations as inore coinplex and dynamic than simple dependencies. ${ }^{131}$ Without explicit coordination, stakeholders engage in a shared and continuous process of information collection and interpretation that exploits the full breadth of perspectives and expertise possessed by different stakeholders. Stakeholders located in remote reaches of the corporation, who are largely passive in the conventional interdependent governance model, may contribute to the interactive governance pro-

130. This phrase is taken from Hayek's characterization of the strengths of market over commandbased systems of resource allocation. F.A. Hayek, The Use of Knowledge in Society, 35 AM. EcoN. REv. 519, 521 (1945).

131. Gilson and Roe have developed a cooperative and somewhat interactive model of stakehoider govemance ("contractual govemance") to describe the operation of the Japanese keiretsu. Ronald J. Gilson \& Mark J. Roe, Understanding the Japanese Keiretsu: Overlaps Between Corporate Governance and Industrial Organization, 102 YALE L.J. 871, 881 -95 (1993). Nevertheless, in stark contrast to our model, Gilson and Roe regard widespread equity investment as the key component to successful stakeholder interaction in the keiretsu. Id. at 887. 
cess even if they have no direct impact on management. Their monitoring enhances the quality of firm governance by conveying timely, front-line information to other stakeholders who have more significant voice capabilities. For ease of reference, we occasionally refer to the former as monitoring stakeholders and the latter as sophisticated or active stakeholders. Sophisticated stakeholders rely on the real-time information provided by monitoring stakeholders to flesh out their understanding of management's performance. Like pieces in a complex puzzle, the bits of information collected by diffuse stakeholders yield limited understanding when viewed alone; when coinbined with other fragments, however, they enable sophisticated stakeholders to discern the true performance of the firm. On the basis of this information, the sophisticated stakeholder can take remedial actions that, in turn, can benefit all stakeholders.

Hence, we now return to the two fundamental claims on which the interactive governance theory rests. First, stakeholders relay valuable information to each other, particularly from stakeholders with less scope for direct influence on firm decisions to more sophisticated stakeholders. Second, the interactivity is justified by the existence of a common goal of firm value nlaximization that is not overshadowed by conflicts in interest among stakeholders. The remainder of this Article exainines these postulates in greater detail, with the aid of two examples of the process at work.

The first claim calls for an elaboration of the means by which signals are communicated among stakeholders. The simplest is direct communication. For example, a production employee may alert a creditor or shareholder of defects in the production process. ${ }^{132}$ Frequently, however, information is conveyed through actions (exit or voice) undertaken by monitoring stakeholders and observed by others. Consistent with the focus of this Article, we are concerned inostly with exit because it has been ignored as a component of corporate governance. Yet, the sale of stock by a shareholder, the termination of deliveries by a supplier or of orders by a custoiner, and the acceleration of debt obligations by a lender often send useful signals to other stakeholders through a variety of channels.

The first example of the interactive model at work concerns Cray Research. The resignation of Dr. Steven Chen from Cray Research illustrates the role of employee monitoring and exit in corporate governance. Through the early and mid-1980s, Cray experienced extremely rapid growth in revenues and earnings from supercomputer production and sales. In 1987, it ascended to the list of Fortune 500 companies, and recorded the highest profit inargin of any company in that group. ${ }^{133}$ However, in

132. Although dissatisfied employees may complain to stronger voice stakeholders (that is, shareholders or board members), uncertainties in the reaction of these stakeholders, in addition to fear over management reprisals, make this a risky strategy.

133. Anatole Kaletsky, Where Does Cray Go Now Chen Has Packed His Bags?, Fin. Times, Sept. 15,1987 , at 14 . 
September of that year, one of its leading engineers, Dr. Steven Chen, resigned. His departure was apparently instigated by a disagreenent with management concerning the pace of development of a new parallel processing technique. In forty-eight hours, Cray's stock plummeted from $\$ 113$ per share to $\$ 97.75$ per share. ${ }^{134}$ The drop in the market value reflected not only the loss of Chen, but arguably also unfavorable information concerning Cray that was signalled by his decision to leave. A leading financial newspaper described the market's reaction to Chen's departure as follows:

At a mininnun, Chen's departure seems to have deflated the image of a company which had come to epitomise that philosopher's stone of high-tech business: a balanced melding of scientific leadership and financial success ....

The fear now is that Chen's resignation and the cancellation of the MP project may point to a dilution of this happy blend of technology and commerce. That Cray, in fact, may be the latest instance of a great American science-based company getting too bureaucratic and too stingy to keep ahead in the technological race. ${ }^{135}$

Chen's resignation sparked a rash of publicity about Cray, much of it expressing concern about Cray's competitiveness in the U.S. and Japanese supercomputer industry. ${ }^{136}$ Thus, Chen's resignation undoubtedly cominunicated information to Cray's investors and other stakeholders about slack in research and development strategy at the company. The message was accentuated by the departure of an additional forty-two employees who left to join Chen in his new supercomputer venture. ${ }^{137}$ Unfortunately, Cray's problems have not disappeared. ${ }^{138}$ As a result, it is admittedly more difficult to demonstrate that Chen's signal instigated a successful correction within the company.

One premise of the interactive model is that sophisticated stakeholders pick up signals from other stakeholders. However, the fact that signals are sent does not assure that the signals can be interpreted correctly. The quality of exit signals varies a great deal. Many signals are cloudy and therefore

134. Id.

135. Id. (emphasis added); see also Lawrence Edelman, Cray's Shares Fall Again As Resignation Clouds Future, Reuter Bus. REP., Sept. 3, 1987 ("The Chen departure has highlighted delays in that program [the design of the new Y-MP line of supercomputers whose shipments were to begin in 1988], which was pushed back about a year, analysts said.").

136. See, e.g., John W. Verity et al., The Hungry Pack Nipping at Cray's Heels, Bus. WeEk, Oct. 26,1987 , at 110 .

137. Terry Fiedler, "If You Build It, They Will Come," 24 ConP. REP. MnN. No. 4, at *3, April, 1993, available in LExIs, NEWS Library, ASAPII File.

138. For the first six months of 1995 , Cray Research, Inc., reported a net loss of $\$ 187,199,000$, or $\$ 7.41$ per share, as compared to net earnings of $\$ 1.16$ per share for the same period in 1994. Cray Research Reports Second Quarter Results, PR NEwSWIRE, July 27, 1995, available in LExIs, NEWS Library, PRNEWS File. 
of limited value. In some cases, the exiting stakeholder herself has incentives to camouflage the signal. For example, a shareholder with a large equity stake wishes to avoid sending an unambiguous signal of slack in the firm until she has sold all ler interest in the company. In inost cases, however, it is likely that the exiting stakeholder has no interest in expending effort or resources either to cloud or to clarify the signal. In the absence of an agreeinent, she is unable to capture any of the benefits from sending a clear signal. Sales of stock in public securities inarkets, for instance, are largely anonymous and therefore the identity of the vendor and the motivation behind the sale are difficult to decode.

However, where there is value in decoding such signals, one would expect appropriate incentives and institutions to evolve. In some circuinstances, the stakeholder may have a selfish interest in clarifying the reasons for exit: for example, an einployee inakes it clear that she chose to leave because of an objectionable state of affairs at her former einployer. In other cases, repeat governance players inay establish conventions that promote the reciprocal conveyance of clear signals across a nuinber of different corporations. Information intermediaries, such as securities analysts or credit rating agencies, facilitate such conventions by decoding anbiguous signals.

As an example of the decoding process that occurs upon the transinission of an ambiguous signal, it is helpful to examine the case of Barneys. In November 1993, the press reported that Barneys, a prominent clothing retailer in New York City, was late in its payments to most of its 7,400 suppliers and that many suppliers had stopped shipping goods to its stores. ${ }^{139}$ In addition, contractors who worked on Barneys' new Madison Avenue store coinplained of similar delays in payment. ${ }^{140}$ The signal from the suspension of deliveries would have been relatively clear but for atteinpts by manageinent to blur the signal by advancing a benign explanation for the disruption in supplies: it had several disputes (or "poor communication") with its suppliers concerning the quality of goods ordered and payment terms. ${ }^{141}$ Barneys also issued cash flow and earning figures purporting to show the financial health of the company. ${ }^{142}$ In the face of conflicting and anbiguous signals, retail analysts and suppliers' organizations provided their respective interpretations based on their own investigations of the signal. For instance, the New York Times quoted the president of

\footnotetext{
139. Amy M. Spindler, Barneys Says It's Healthy; Vendors Fret, N.Y. Times, Dec. 17, 1993, at D1.

140. Id.

141. Id.

142. As a privately held company, Bameys had no obligation to disclose this financial information. Its figures showed earnings before interest, taxes, depreciation, and amortization of $\$ 6.7$ million for the quarter ended October 31 , up from $\$ 3.9$ million a year earlier. Id. at D6. In the face of ongoing skepticism, the company's management was forced to release even more detailed financial data (including projected financial results) to suppliers, factoring companies, and finaneial newspapers. See Barneys New York Opens Books to Ease Concerns, Reuters, Limited, Fin. Rep., Feb. $25,1994$.
} 
Barnard's Retail Consulting Group and the publisher of The Retail Marketing Report: "'The arrogance of Barneys is legendary,' he said. 'But in this instance it seems a cover-up for internal financial pressures." "143

Ultimately, the rumors respecting Barneys' payment difficulties were communicated to other stakeholders, namely investors who were conteinplating a $\$ 55$ million private debt offering. In contrast to a straight debt offering that had been concluded early in 1993, concerns over the financial condition of Barneys required that the company both provide security for the additional funds and pay a higher premium. ${ }^{144}$ This suggests that the exit decisions by suppliers conveyed important information to more sophisticated institutional investors who were then able to inpound this information into the terms of their debt contracts with Barneys. Thus, the suspension of deliveries by suppliers (a form of exit) can provoke a public response from management, as well as investigation by information intermediaries who are paid to transmit and decode such signals.

Given that stakeholders can and do monitor each other's signals, and can properly interpret these signals, we now turn to the second assumption underlying our theory: that stakeholders share common goals and interests that outweigh their conflicting interests. This is best established indirectly by showing that special rules niodify the governance system when the conflicting interests become too strong. While stakeholder interests in solvent firms normally coalesce around the goal of controlling managerial slack, this convergence weakens as the financial condition of the firm deteriorates. ${ }^{145}$ Shareholders of a distressed firm are more intent on persuading their managers to gamble the firm's way back to prosperity than debtholders who, as a group, have the opposing preoccupation with containing losses. Individual creditors strive to improve their priority position relative to others, while customers with outstanding orders urge the firm to deliver to avoid having their contractual rights liquidated into unsecured claims. Employees, like managers, simply want to keep their jobs. The conventional premise in governance models is that managers are agents, albeit imperfect, of their shareholders. However, it is more realistic to presume that, to the extent that managers are prevented from pursuing their self-interest exclusively, one or inore nonequity constituencies may also affect managerial decisions. Yet, there is no a priori pattern of shared influence among heterogeneous constituencies. In sum, while significant gains are yielded by interactive corporate governance, it is inportant to

143. Spindler, supra note 139 , at D6.

144. Tom Kershaw, Market Roundup, INvestment Dealers' Dig., Jan. 3, 1994, at *2, available in Lexis, NEWS Library, ASAPII File.

145. In fact, conflicts may exist to some degree even in solvent states of the firm when, for instance, lenders (particularly with priority) are less concerned about managerial slack (for example, compensation and consumption of perquisites) than residual claimants from whose pockets these payments are drawn first. 
underscore the often-fragile compacts that undergird these activities, and the corresponding role for institutional design im ameliorating conflicts among stakeholders. As we observed in Part II in the context of the exit and voice of bank lenders, various legal and economic forces emerge over time to mitigate the agency problems between active and passive stakeholders, while preserving the benefits from interactivity.

\section{CONCLUSION}

In this Article, we have set out the contours of an alternative theory of corporate governance-interactive corporate governance-that emphasizes the extensive and quite complex array of interactions that occur among stakeholders in the modern firm in response to managerial slack. We did so by analyzing the role of bank debt in the American system of corporate governance. Although reaction to slack can occur via either voice or exit mechanisms, we focused our efforts on demonstrating the value of the latter. We also sought to explore the role of legal rules and organizational arrangements that channel the exit decisions of individual stakeholders for the benefit of the firm as a whole. Indeed, an interactive process that may be triggered anywhere within the web of contracts in the firm may explain the virtue of the American corporation today-its flexibility and adaptability.

The development of the interactive corporate governance theory raises several issues that are fruitful for further research. First, the theory's structure could benefit from the insight of game theory, particularly regarding the incentives for stakeholders to deliberately suppress their exit decisions from the purview of other, more sophisticated, corporate actors, and the ways in which these incentives can be modified. Second, the positive value of the theory should be assessed against a broader array of stakeholder interactions than the ones we have addressed. Among the more interesting is the relatively neglected area of shareholder and einployee interdependence. Specifically, what institutions exist to ensure that private information respecting managerial slack is transmitted to shareholders and/or directors in real time? Third, the interactive theory of corporate governance contains several unexplored implications for the current debate over the relative efficiency of foreign versus domestic systems of corporate governance, and, in particular, the governance role of banks in those systems. ${ }^{146}$ The frequently expressed concern is with the restrictive impact of American

146. Michael Porter, Remarks at the Securities and Exchange Commission Conference on Corporate Governance and American Competitiveness (Mar. 19 and 20, 1992); see also Mark J. Roe, Some Differences in Corporate Structure in Germany, Japan, and the United States, 102 YALE L.J. 1927, 1948-56 (1993) (identifying the sometimes cumbersome political constraints placed on U.S. banks). For two lucid responses to Roe's argument see J. Mark Ramseyer, Columbian Cartel Launches Bid for Japanese Firms, 102 YALE L.J. 2005 (1993) (responding to Roe and others who seek to blame the American system of corporate governance for lackluster U.S. economic performance) and Roberta Romano, A Cautionary Note on Drawing Lessons From Comparative Corporate Law. 102 YAlE L.J. 
banking legislation on the size of, and activities carried out by, American banks. Specifically, the claim is that because American banks historically could not invest in equities, their governance role was subverted. Nevertheless, the interactive theory we have developed suggests that specialized-albeit fragmented-monitoring and reaction by diffuse stakeholders can be rationally integrated into the governance process. If so, our theory suggests that bank equity restrictions may not have had a disabling impact on American corporate governance.

2021 (1993) (questioning Roe's assumption that the restraints placed on U.S. banks are necessarily a bad thing). 
